\title{
Synthesis approach-dependent antiviral properties of silver nanoparticles and nanocomposites
}

\author{
Jaison Jeevanandam ${ }^{1}$ - Saravanan $\mathrm{Krishnan}^{2} \cdot$ Yiik Siang Hii $^{3}$. Sharadwata Pan $^{4} \cdot$ Yen San Chan ${ }^{5}$. Caleb Acquah ${ }^{6}$. \\ Michael K. Danquah ${ }^{7}$. João Rodrigues ${ }^{1,7}$
}

Received: 30 July 2021 / Accepted: 2 December 2021 / Published online: 15 January 2022

(c) The Author(s), under exclusive licence to Islamic Azad University 2021

\begin{abstract}
Numerous viral infections are common among humans, and some can lead to death. Even though conventional antiviral agents are beneficial in eliminating viral infections, they may lead to side effects or physiological toxicity. Silver nanoparticles and nanocomposites have been demonstrated to possess inhibitory properties against several pathogenic microbes, including archaea, bacteria, fungi, algae, and viruses. Its pronounced antimicrobial activity against various microbe-mediated diseases potentiates its use in combating viral infections. Notably, the appropriated selection of the synthesis method to fabricate silver nanoparticles is a major factor for consideration as it directly impacts antiviral efficacy, level of toxicity, scalability, and environmental sustainability. Thus, this article presents and discusses various synthesis approaches to produce silver nanoparticles and nanocomposites, providing technological insights into selecting approaches to generate antiviral silver-based nanoparticles. The antiviral mechanism of various formulations of silver nanoparticles and the evaluation of its propensity to combat specific viral infections as a potential antiviral agent are also discussed.
\end{abstract}

\section{Graphical abstract}

Physical synthesized silver nanoparticles

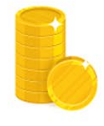

Costly

Limitations of conventional synthesis approaches
Chemical synthesized

silver nanoparticles

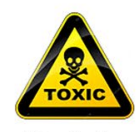

Toxicity

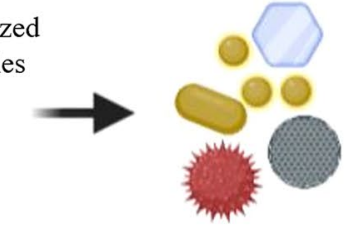

Biosynthesized Silver nanoparticles

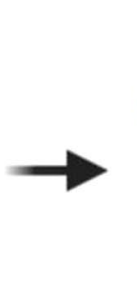

Inhibits SARS-CoV-2

via binding with spike protein

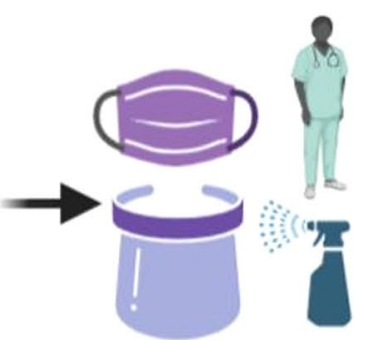

Future antiviral mask, apron, shield and disinfectant with silver nanoparticles

Keywords Silver nanoparticles · Antimicrobial $\cdot$ Viral infection · Nanoformulation · Antiviral $\cdot$ Toxicity

\section{Introduction}

Jaison Jeevanandam

jaison.jeevanandam@staff.uma.pt

$\bowtie$ João Rodrigues

joaoc@staff.uma.pt; joaor@uma.pt

Extended author information available on the last page of the article
Nanoscience or nanotechnology is a branch of science elucidating the chemistry of nanoparticles. Nanoparticles are synthesized by assembling a group of atoms or molecules of different materials with a size of one billionth of a meter or $10^{-9} \mathrm{~m}[1,2]$. There are varied types of nanoparticles, including metal, metal oxide, polymer, carbon based, and 
composites, which can be fabricated based on the desired applications [3-5]. Among these nanostructured particles, metal nanoparticles are widely used and are under extensive research for applications in electronics, textiles, sensors, and nanomedicine [6, 7]. Nanosized gold and silver particles are the most common metal nanoparticles used in a broad spectrum of applications, particularly biomedical applications [8, 9]. Silver nanoparticles (AgNPs) possess several unique properties, depending on their size, morphology, and surface charge [10] that inspire various biological applications. AgNPs have been employed in biomedical applications such as biosensors, bioimaging, disease treatment, drug delivery, and nutraceuticals [11]. AgNPs are known for their enhanced antimicrobial activity against several pathogenic microbes, such as bacteria, fungi, algae, and viruses [12]. However, the rapid oxidation characteristics of AgNPs and the high dependency of the stability of AgNPs on the surface charge of the suspending media significantly limit the use of AgNPs [13]. Therefore, AgNPs have been incorporated into nanocomposites to enhance stability [14], to address stability and rapid oxidation limitations. It is worthy to note that the properties of AgNPs are mostly dependent on the synthesis procedures, which determines the size, morphology, surface charge, and biocompatibility of the nanoparticles for desired applications [15].

Numerous viral infections are common among humans and some can even lead to death. Viruses are natural nanosized particles that cause infections [16]. Even though conventional antiviral agents effectively treat viral infections, they may lead to side effects or toxicity towards normal healthy cells or other important metabolic microbes. Various researchers have recommended AgNPs and nanocomposites as promising antiviral agents to combat various viral infections as they have demonstrated efficacious antiviral properties against well-known viruses, including influenza and human immunodeficiency virus (HIV) $[17,18]$. However, the approach used for AgNPs synthesis is critical to tune the physicochemical characteristics and antiviral properties of AgNPs for different viral infections. Physical and chemical approaches can be used to generate stable nanoparticles. However, cytotoxicity remains a major limitation for their use as antiviral agents in biomedical applications [6]. The biosynthesis approach offers the possibility to produce nanoparticles with less or no toxicity. However, the yield of the final product, stability, and antiviral potency of biosynthesized nanoparticles can be compromised [19]. Thus, this article aims to discuss various approaches for the synthesis of AgNPs and nanocomposites and provide unique characteristics of the synthesis approaches that are essential to optimize the molecular, structural, and antiviral properties for enhanced and tailored biomedical applications.

\section{Overview of AgNPs and nanocomposites}

Silver is a noble metal from group 11 of the periodic table of elements. Further, silver predominately exists in oxidation states of +1 , which is stable in an aqueous solution as $\left[\mathrm{Ag}\left(\mathrm{H}_{2} \mathrm{O}\right)_{2}\right]^{+}$. Generally, silver nitrate $\left(\mathrm{AgNO}_{3}\right)$ is the metal precursor used for the bottom-up synthesis of AgNPs, where the oxidation state of Ag is zero [20]. The reduction equation in the conversion of ionic silver (aqueous state) to zerovalent silver atoms (solid state) is given in Eq. (1).

$\mathrm{Ag}_{(\mathrm{aq})}^{+}+\mathrm{e}^{-} \rightarrow \mathrm{Ag}_{(\mathrm{s})}^{0}$,

$E^{0}=0.80 \mathrm{~V}$ (standard electrode potential) (at $\left.298 \mathrm{~K}\right)$.

In general, tunneling effects are higher in silver nanomaterials leading to the greater surface to volume ratio, where more surface atoms are exposed to exhibit large surface energy, spatial confinement, and reduced imperfections [21]. Due to these exciting features, silver nanomaterials possess unique physical, chemical, and mechanical properties, compared to their bulk counterparts [22]. Notably, the exclusive properties of silver nanoparticles differ within the nanometer scale, with the particle size as well as its characteristics, determining the scope of properties of a nanomaterial [23]. Thus, silver nanostructures can be classified based on various ways. The most accepted classification of silver nanostructures is based on dimensions (electronic confinement), as displayed in Fig. 1.

The effect of the size of the nanoparticles is one of the most studied parameters for biomedical applications. For instance, the enhanced antimicrobial properties of AgNPs, compared to bulk silver and silver ions can be related to the nanosize of the particles [28, 29]. In principle, smallsized AgNPs (typically below $100 \mathrm{~nm}$ ) show high biocidal activity due to their larger surface area, compared to their bulk counterparts (micro-sized particles) [30]. In addition to size, parameters such as crystallographic structures and shapes of silver nanostructures affect antimicrobial activity [31, 32]. Further, microbial growth, which causes infectious diseases, can be eradicated by bioaerosols' disinfection and water using antimicrobial agents [33]. It is worthy to note that AgNPs can be incorporated into fabrics to produce antimicrobial textiles for clinics [34]. Furthermore, AgNPs have been demonstrated via in vitro and in vivo studies to significantly influence wound healing owing to its antiinflammatory properties [35, 36]. Moreover, the intrinsic targeted microbial cell inhibition potential of AgNPs are used to prepare enhanced antibacterial, antifungal, and antiviral agents, as evident from their properties illustrated in Fig. 2 [10]. Besides, AgNPs also have anticancer [37], antiangiogenic [38] and antiproliferative effects, depending on their size and shape [39]. 
Fig. 1 Classification of silver nanostructures based on dimensions, such as silver nanoparticles (electronically confined in all directions), reproduced with permission from [24], IOP Science, 2017; silver nanorods (electronically confined in two dimensions), reproduced with permission from [25], Elsevier, 2018; silver nanoplates (electronically confined in one dimension), reproduced with permission from [26], Hindawi, 2011 and silver nanocubes (electronically unconfined in any dimension), reproduced with permission from [27], Nature, 2015
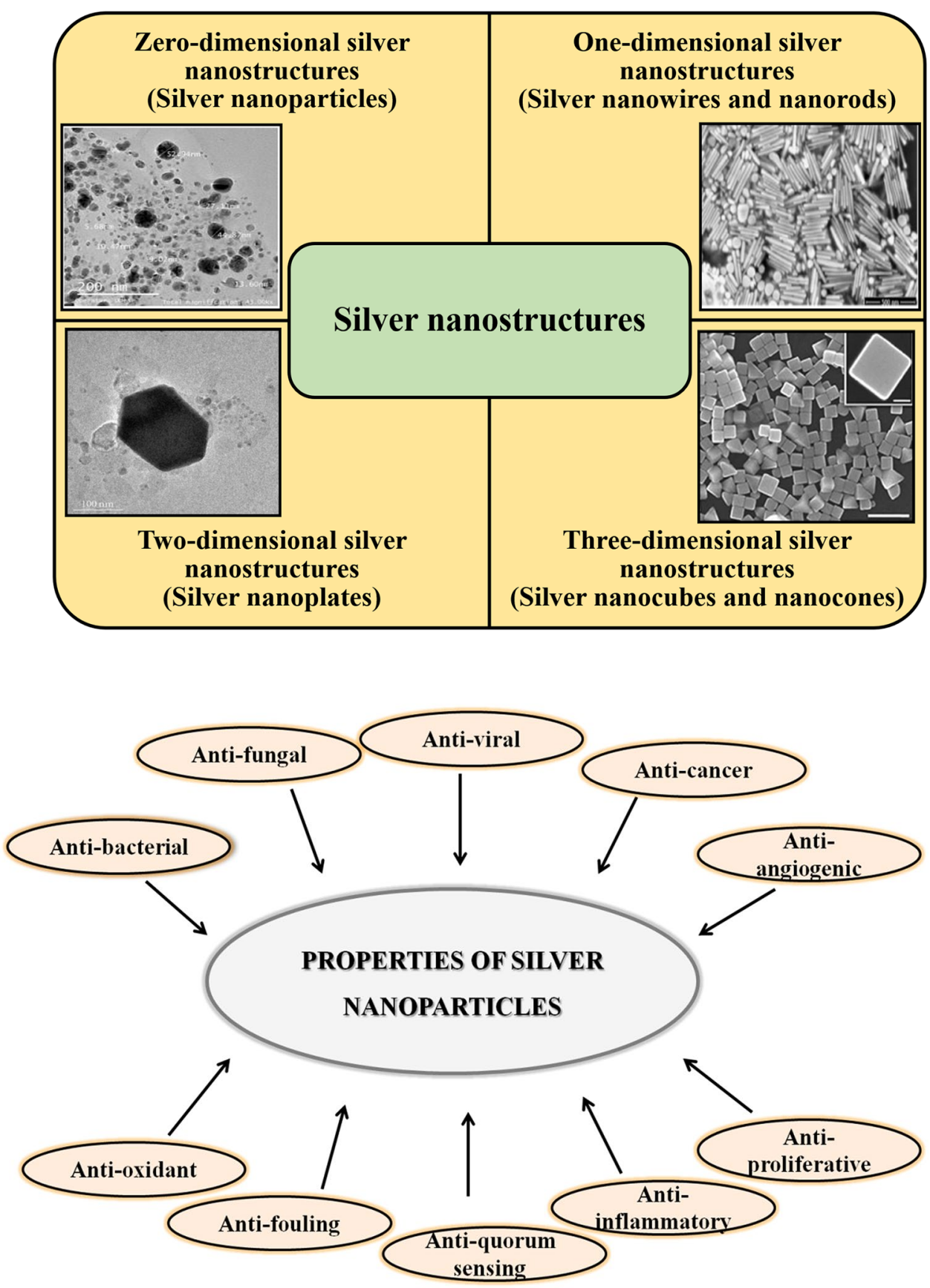

Fig. 2 Properties of AgNPs for biomedical applications
Silver nanocomposites are formed by embedding nanosized silver particles with other nanomaterials or matrices to explore synergistic functionalities. Overall, nanocomposites may contain one or more matrices such as resin/ polymer-based, inorganic nanoparticles, carbon, polysaccharide, silica, and chitosan. Properties of silver nanocomposites usually depend on the stabilizing matrix that is used for the dispersion of AgNPs [40]. Further, silver nanocomposites can be classified as magnetic and nonmagnetic, depending on the magnetic nature of composite matrices associated with silver nanostructures.
Silver nanocomposites can be formed with magnetic properties if it contains one or more magnetic nanoparticles ( $\mathrm{Fe}, \mathrm{Co}, \mathrm{Cr}, \mathrm{Ni}, \mathrm{Gd}$ ). These magnetic nanocomposites have the advantage of being reused several times and this property can be explored in several applications, such as pollutant removal, magnetic resonance imaging (MRI) technique, and magnetic separation of immune cells [41]. Magnetic nanoparticles can be used to harbor materials and release them, enabling reuse of the magnetic nanoparticles. For example, if pollutants materials are bound on magnetic nanoparticles as supports, demagnetization can be used to dislodge the 
bound materials from the nanoparticles surface to enable reuse application. Likewise, non-magnetic silver nanocomposites, that are fabricated by incorporating carbon, polymer, resin, cellulose, and silica, are beneficial in improving the biological and mechanical properties of silver nanoparticles as well as to reduce their cytotoxicity in certain cases [42-47]. Therefore, it can be noted that nanocomposites are widely used in various biomedical applications. However, the synthesis approach plays a major role in tailoring the properties of nanoparticles and nanocomposites for desired applications.

\section{Synthesis approaches of AgNPs}

The appropriate selection of a synthesis approach is the most significant step in the fabrication of nanoparticles. The synthesis method is highly beneficial in selecting precursor, reducing, and stabilizing agent required for the reaction, as well as for determining the size, morphology, and surface charge of the nanoparticles. These physicochemical characteristics of nanoparticles are critical in influencing the nanoparticles' properties to be utilized in specific applications [48]. AgNPs can be synthesized by physical, chemical, and/or biological approaches. The nanoparticles growth mechanism plays a significant role in determining the morphology of the resulting AgNPs, which can affect their physicochemical properties [49]. Most of the physical synthesis methods transform the bulk sized silver particles into silver nanopowders via top-down approaches. Conversely, chemical and biological synthesis methods utilize bottom-up approach to reduce silver precursors into silver ions, which later undergoes nucleation, nuclei growth, and coalescence to form nanosized silver particles, as displayed in Fig. 3 [50]. Among nucleation and growth mechanism, LaMer, Ostwald ripening, Finke-Watzky, intra-particle growth, coalescence, and oriented attachment are the common theories proposed for nanoparticle formation via chemical and biological synthesis [51]. Since several works are available regarding the synthesis of AgNPs, this discussion focuses on the latest reported studies (2016-2020), where various types of AgNPs are fabricated using specific synthesis approaches.

\section{Physical approach}

The physical method represents the use of mechanical or forms of energy other than chemicals to fabricate AgNPs. Ball milling, spray pyrolysis, laser pyrolysis, laser ablation, electrospinning, melt mixing, inert gas condensation, and physical vapor deposition are the standard physical methods, which mainly rely on top-down approaches (bulk/microsized particles are reduced to form nanoparticles) to fabricate AgNPs [52]. Ball milling (BM) is the most common

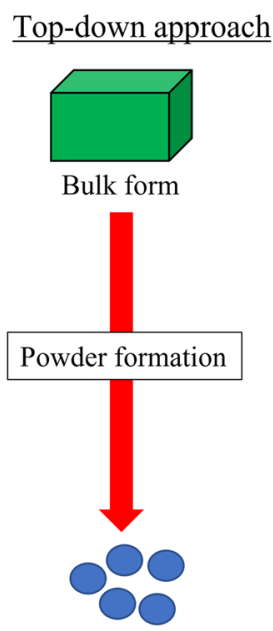

Silver nanoparticles

Physical method

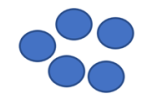

Silver nanoparticles

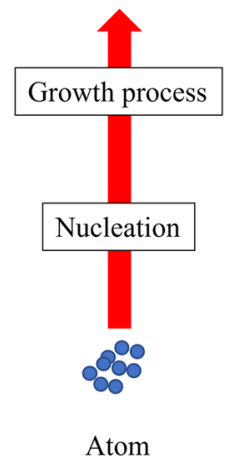

Chemical and biological method
Bottom-up approach

Fig. 3 Schematic representation of particle nucleation, growth, and formation of nanoparticles via physical, chemical, and biological methods. Adopted from [50], () Lee and Jun, 2019. MDPI

mechanical-based physical method where the macroscopic precursors will be crushed by the balls in a mill at high energy to produce nanosized particles [53]. This approach is highly beneficial, producing very fine powder of particle size less than $100 \mathrm{~nm}$, being used for continuous process, and forming highly abrasive materials. However, product contamination due to the wear and tear of balls, the requirement of long milling time, high machine noise level, and tedious machine cleaning are some of the limitations of the BM method in silver nanoparticle synthesis [54]. Thus, high-energy ball milling (HEBM) approach is introduced to overcome the limitations of the conventional ball milling method [55].

Laser ablation (LA) is another method of fabricating nanoparticles by removing materials from a solid surface using a focused pulsed laser beam [56]. This method is used to synthesize AgNPs with minimal heat transfer and low cost without less toxicity toward the environment [57]. However, the yield of low silver nanoparticle concentration in the solution and the use of high-energy lasers are the main limitations of this method, which will eventually increase the cost of synthesis and affect the antimicrobial activity of the nanosized silver [58]. The electrospinning approach is a common method to fabricate AgNPs embedded in polymer-based fibers via electric force by drawing charged polymer threads or polymer melts [59]. The advantages of this method are the simplicity and efficiency of the procedure, inexpensiveness, and the ability to control factors such as AgNPs size, fiber orientation, diameter, and composition. However, the use of toxic organic solvents and the restricted control over pore structures are the limitations of this approach in the 
fabrication of AgNPs [60, 61]. Also, melt mixing (MM) [62], inert gas condensation [63], sputtering [64], dielectric barrier discharge (DBD) [65] and physical vapor deposition (PVD) [66] are also applied for silver nanoparticle production. However, the methods' complexity makes these approaches suitable for silver-based nanocomposite fabrication rather than pure nanosized silver particles.

\section{Chemical approach}

Chemical synthesis methods are the most common and widely used nanoparticle fabrication approach via bottomup approach (ions nucleate and grow to form nanoparticles) by utilizing synthetic chemicals as reducing and stabilizing agents. These methods include sol-gel, precipitation, polyol, hydrothermal, and other novel approaches to synthesize AgNPs [49]. Sol-gel is one of the unique wet chemical processes used for silver nanoparticle fabrication, which involves hydrolysis, polycondensation, gelation, aging, drying, densification, and crystallization [67]. The major advantages of the sol-gel approach in silver nanoparticle synthesis are the use of relatively low temperature, a yield of fine nanopowders, and the production of AgNPs with unattainable compositions via solid-state fusion. However, the high cost of precursors and shrinkage of the wet gel upon drying, which can lead to damage or agglomeration of nanoparticles, are the limitations of using the sol-gel approach to produce silver nanoparticles on a large scale [68].

Polyol is another chemical method used to produce AgNPs in which the metal precursors are suspended in a glycol solvent followed by heating the mixture to reflux [69]. This approach's advantages are the chelating ability of polyol to control nucleation, growth, and agglomeration of nanoparticles and the reduced ability at a high temperature, which eventually reduces the silver precursor solution to form nanosized silver [70]. However, restricted, reducing power, and insufficient stabilization of non-polar metal surfaces via polar polyol are the limitations of this method [71]. The hydrothermal or solvothermal approach is another widely used method for silver nanoparticle fabrication in which a high vapor pressure level and a high-temperature aqueous solution will be employed to form nanosized crystals [72]. Implementation of solubility via pressure and heat at a critical point, enhancement in chemical properties, ease in the synthesis of intermediate, metastable state and specific phase products, precise control of size, morphology, and crystallinity are the advantages of this method to fabricate AgNPs. However, limitations such as the requirement of expensive autoclaves, safety issues, and inability to follow the prevailing reactions restrict their usage in the commercial production of AgNPs [73]. Moreover, solution combustion [74], simple chemical reduction [75], and electrochemical approach [76] are the other chemical methods used to synthesize AgNPs. However, the complexity and formation of non-uniform nanoparticles are the major limitations restricting the utilization of these methods for largescale nanosized silver particle preparation.

\section{Biological approach}

Biological (plant or microbially derived reducing and stabilizing agents) and green approaches were introduced to manufacture AgNPs, as physical and chemical approaches required costly equipment, high energy and/or toxic chemicals [77]. Whilst plant and microbial extract-based synthesis fall under green synthesis, the definition of green synthesis goes beyond the type of extract. It encompasses the entire upstream and downstream steps (in terms of material and energy use) and their impacts on the environment. For biological synthesis, biochemicals are extracted from living organisms such as bacteria, fungi, algae, and plants and used to reduce and stabilize agents to form nanosized particles via bottom-up approaches (Rónavári et al. 2017). In most biogenic synthesis methods, heat is used to initiate the nucleation of the nanoparticles [78]. However, microwave, ultrasound, and light (visible, ultraviolet, laser, and infrared irradiation/photocatalytic reduction) are currently used as initiators in biogenic reactions as direct thermal heat can denature the biomolecules of interest in the reaction [79]. AgNPs synthesized from the biomolecules extracted from the microbes, or intracellular synthesis approaches, are common biogenic methods that are still under extensive research [80, 81].

It can be noted that the majority of AgNPs synthesized via physical and chemical approaches are identified to be toxic or leads to adverse effects on the environment (soil/ water) and affect seed germination and crop yield [82-85]. The major advantage of utilizing microbial extracts is the toxicity reduction on the prepared nanoparticles and the ability to use less energy when compared to physical and chemical approaches. However, large-scale synthesis, a dependency of microbial doubling rate, contamination of culture medium, and agglomeration of nanoparticles are the major limitations of this method [86]. Thus, plant extracts are introduced as a potential alternative natural biochemicalbased reducing and stabilizing agent for the fabrication of $\mathrm{AgNPs}$, as no pre-processing is required, unlike microbial synthesis, which requires optimization of culture medium, and the plants are widely available throughout the world [87]. Even though nanoparticles can be fabricated from all the parts of plants, leaves are the most significant part. They can grow faster, do not affect plant development, and contain several secondary metabolites, which is essential as a natural reducing and stabilizing agent for the formation of nanoparticles [88]. Although this approach can yield less-toxic nanoparticles with the ability to manipulate their size and 
shape, agglomeration and less stability of the nanoparticles are the major limitations of this method [89].

All the biogenic approaches for the fabrication of AgNPs usually utilize heat as an energy transfer source to modify the extracted biomolecules and use them as a potential reducing and stabilizing agent to rapidly form nanosized particles [90]. Despite the conventional heat-based biogenic approach yielding smaller non-toxic nanoparticles, the energy required throughout the process is high, limiting the claim of green synthesis [91]. Thus, microwave, light, and ultrasound have been introduced as alternative energy sources to form nanosized particles, especially for plant leaf extract-mediated biogenic synthesis, as they can reduce the reaction time [92]. However, the limitations of this approach are the safety of fabricating metal nanoparticles and the disruption of biomolecules due to excessive heat via microwave, solar/visible/UV/infrared light. In addition, the yield of AgNPs from these alternative methods is less with low stability than the chemical synthesis method, which is the major limitation of this approach for large-scale applications [93]. Table 1 summarize different synthesis methods to fabricate AgNPs, along with their advantages and limitations.

\section{Synthesis approaches of silver nanocomposites}

Recently, various strategies have been reported pertaining to the fabrication of silver nanocomposites, similar to AgNPs. These can be broadly categorized based on their fundamental nature as summarized in Table 2.

\section{Physical approach}

The physical approach of silver nanocomposite fabrication mainly incorporates the use of laser impulse energy to decrease silver from macrostructures to atoms and ions [94]. In this context, various approaches have been documented in the literature regarding the synthesis of AgNPs/polymer nanocomposites. Yeo et al. reported silver nanoparticle film synthesis on polyethylene terephthalate or PET substrate via the roll-to-roll method. The authors utilized thermal and laser hardening actions to enhance the conductivity of the silver nanoparticle films [95]. Likewise, one area of imminent application is the fabrication of nanofibers incorporating AgNPs. It has been demonstrated by Zhang et al. that the procedure to incorporate AgNPs with nanofibers is similar to the polymer nanocomposite formation, where AgNPs, synthesized via either physical, chemical, or biological approaches, are dispersed initially into a polymer matrix. This is followed by either the process of laser ablation or chemical reduction, including additional procedures to form silver embedded nanofibers. However, there are several aspects to consider. For instance, it can be either a one-step or a two-step methodology. While the one-step method utilizes the identical solvent for the involved polymer and the silver precursor, the two-step approach mainly involves the silver particle reduction and nanofiber synthesis separately via distinct solvents, and hence may guarantee more applications [94]. Similarly, the production of silver nanofibers is facilitated by the employment of the electrospinning process to a great deal $[94,96]$. The process is usually marked by the application of high voltage to transform a polymer solution into nanofibers. This process is influenced by several parameters, including solution concentration and characteristics, capillary tube pressure, electric potential at the capillary tip, and chamber circumstances, amongst others [96].

In recent times, graphene oxide nanosheets have also been loaded with AgNPs to form composites using various physical means, such as sonication, microwave, and pulsed methods [97, 98]. However, instances of associated deleterious outcomes, including inhomogeneity, agglomeration, varying size, and spread, amongst others, have marred their positive evaluations to a considerable extent [99]. Further, silver nanoparticle-cellulose nanocomposites have also been reported to be synthesized following various physical methods, such as wet process and dry process ([100]; and references therein). Moreover, distinct techniques highlighting the physical approach have been reported to be utilized to fabricate silver nanoparticle-chitosan composites ([101]; and references therein). Furthermore, thermal methods, such as the freeze-drying technique, as well as specific substances, such as carboxymethyl chitosan and polyvinylpyrrolidone, have been incorporated to synthesize chitosan-silver nanocomposites, with a variety of reducing and/or stabilizing/ defensive agents [102-104]. However, the physical synthesis process is tedious, require longer reaction time and involves costly equipment for large-scale nanocomposite fabrication.

\section{Chemical approach}

Among different methods highlighting the chemical way of silver nanocomposite synthesis, both in situ and ex situ polymerization procedures embody effective strategies. The ex situ polymerization process is more suited to a large-scale commercial application than the in situ [105]. The chemical approach can also be utilized to synthesize nanofibers comprising AgNPs, as discussed in the previous section "Physical approach". Further, the challenges related to the fabrication of graphene oxide-silver nanocomposites via physical approach, as discussed earlier in "Physical approach" section, have been reported to be alleviated to a considerable extent using specific chemical synthesis approaches. One amongst them is through the introduction and subsequent binding of the thiol (-SH) groups to the graphene oxide (GO-SH) [106]. This approach has its intrinsic benefits, 
Table 1 Advantages and limitations of various synthesis methods for AgNPs synthesis

\begin{tabular}{|c|c|c|}
\hline Synthesis method & Advantages & Limitations \\
\hline \multicolumn{3}{|l|}{ Physical approach } \\
\hline Conventional ball milling & $\begin{array}{l}\text { Very fine powder of particle size less than } 100 \mathrm{~nm} \\
\text { Utilizable for continuous process } \\
\text { Yield highly abrasive materials }\end{array}$ & $\begin{array}{l}\text { Product contamination due to wear and tear of } \\
\text { balls } \\
\text { Require long milling time } \\
\text { High machine noise level } \\
\text { Tedious to clean the machine [54] }\end{array}$ \\
\hline Laser ablation & $\begin{array}{l}\text { Synthesizes AgNPs with minimal heat transfer } \\
\text { Low cost without less toxicity toward the environ- } \\
\text { ment [57] }\end{array}$ & $\begin{array}{l}\text { Yield of low silver nanoparticle concentration in } \\
\text { the solution } \\
\text { Use of high-energy lasers [58] }\end{array}$ \\
\hline Electrospinning & $\begin{array}{l}\text { Simplicity and efficiency of the procedure } \\
\text { Inexpensiveness and ability to control factors, } \\
\text { such as fiber orientation, diameter, and compo- } \\
\text { sition }\end{array}$ & $\begin{array}{l}\text { Utilization of toxic organic solvents } \\
\text { The restricted control over pore structures }[60,61]\end{array}$ \\
\hline $\begin{array}{l}\text { Melt mixing, inert gas condensation, } \\
\text { physical vapor deposition }\end{array}$ & Smaller sized nanoparticles & The complexity of the methods \\
\hline \multicolumn{3}{|l|}{ Chemical approach } \\
\hline Sol-gel & $\begin{array}{l}\text { Use of relatively low temperature } \\
\text { Yield of fine nanopowders } \\
\text { Fabrication of compositions that are impossible } \\
\text { via solid-state fusion }\end{array}$ & $\begin{array}{l}\text { High cost of raw materials } \\
\text { Shrinkage of the wet gel upon drying [68] }\end{array}$ \\
\hline Polyol approach & $\begin{array}{l}\text { The chelating ability of polyol to control nuclea- } \\
\text { tion } \\
\text { Growth and agglomeration of nanoparticles } \\
\text { The reduced ability at high temperature [70] }\end{array}$ & $\begin{array}{l}\text { Restricted reducing power } \\
\text { Insufficient stabilization of non-polar metal sur- } \\
\text { faces via polar polyol [71] }\end{array}$ \\
\hline Hydrothermal or solvothermal approach & $\begin{array}{l}\text { Implementation of solubility via pressure and } \\
\text { heat at a critical point } \\
\text { Enhancement in chemical properties } \\
\text { Ease in the synthesis of intermediate } \\
\text { Metastable state } \\
\text { Specific phase products } \\
\text { Precise control of size, morphology and crystal- } \\
\text { linity }\end{array}$ & $\begin{array}{l}\text { Requires expensive autoclaves } \\
\text { Safety issues } \\
\text { Impossible to observe reactions prevails [73] }\end{array}$ \\
\hline $\begin{array}{l}\text { Solution combustion, simple chemical } \\
\text { reduction, electrochemical approach }\end{array}$ & Smaller sized nanoparticles & $\begin{array}{l}\text { Complexity } \\
\text { Formation of non-uniform nanoparticles } \\
\text { Toxicity [48] }\end{array}$ \\
\hline \multicolumn{3}{|l|}{ Biological approach } \\
\hline Microbial synthesis & $\begin{array}{l}\text { Small size } \\
\text { Ability to alter the shape } \\
\text { Less toxicity } \\
\text { Comparatively less energy }\end{array}$ & $\begin{array}{l}\text { Large-scale synthesis } \\
\text { Dependent on the microbial doubling rate } \\
\text { Contamination of culture medium } \\
\text { Agglomeration of nanoparticles }\end{array}$ \\
\hline Plant mediated synthesis & $\begin{array}{l}\text { No pre-processing is required } \\
\text { Widely available through the world }\end{array}$ & $\begin{array}{l}\text { Agglomeration } \\
\text { Less stability }\end{array}$ \\
\hline Conventional heat & $\begin{array}{l}\text { Smaller size } \\
\text { Shape manipulation }\end{array}$ & $\begin{array}{l}\text { Disruption of biomolecules } \\
\text { Low stability } \\
\text { High energy requirement }\end{array}$ \\
\hline Microwave & $\begin{array}{l}\text { Smaller size } \\
\text { Shape manipulation } \\
\text { Rapid synthesis }\end{array}$ & $\begin{array}{l}\text { Unsafe to fabricate metal nanoparticles } \\
\text { Disruption of biomolecules }\end{array}$ \\
\hline Light & $\begin{array}{l}\text { Smaller size } \\
\text { Shape manipulation } \\
\text { Rapid synthesis }\end{array}$ & $\begin{array}{l}\text { Unstable nanoparticles } \\
\text { Agglomeration }\end{array}$ \\
\hline Ultrasound & $\begin{array}{l}\text { Smaller size } \\
\text { Shape manipulation } \\
\text { Rapid synthesis }\end{array}$ & $\begin{array}{l}\text { Unstable nanoparticles } \\
\text { Agglomeration } \\
\text { Less yield }\end{array}$ \\
\hline
\end{tabular}


Table 2 Summary of various fabrication strategies to yield silver nanocomposites

\begin{tabular}{|c|c|c|c|}
\hline Type & Approach & Fabrication strategy/technique & References \\
\hline \multirow[t]{6}{*}{ Polymer-based silver nanocomposites } & \multirow[t]{4}{*}{ Physical } & Roll-to-roll & {$[95]$} \\
\hline & & Roll-to-roll printing & {$[117]$} \\
\hline & & Dip-coating & {$[118]$} \\
\hline & & Compression & [119] \\
\hline & \multirow[t]{2}{*}{ Chemical } & In situ polymerization & {$[105]$} \\
\hline & & Ex situ polymerization & {$[120,121]$} \\
\hline \multirow[t]{3}{*}{ Silver nanofiber composite } & Physical & Electrospinning & {$[94,96]$} \\
\hline & \multirow[t]{2}{*}{ Chemical } & One-step method & {$[122]$} \\
\hline & & Two-step process & {$[123]$} \\
\hline \multirow{11}{*}{$\begin{array}{l}\text { Graphene/graphene oxide (GO)-based silver } \\
\text { nanocomposites }\end{array}$} & \multirow[t]{4}{*}{ Physical } & Sonication, microwave and pulsed methods & {$[97,98]$} \\
\hline & & Single-step protocol & {$[124]$} \\
\hline & & Electron beam irradiation & {$[125]$} \\
\hline & & Lased ablation synthesis & {$[126]$} \\
\hline & \multirow[t]{3}{*}{ Chemical } & Thiol $(-\mathrm{SH})$ grafting & {$[106]$} \\
\hline & & Modified photochemical method & [127] \\
\hline & & Linking polymer strategy & {$[115,128,129]$} \\
\hline & \multirow[t]{4}{*}{ Biological } & Green functionalization policy & [111] \\
\hline & & Hummers method & {$[112]$} \\
\hline & & Modified Hummers method & {$[124,130]$} \\
\hline & & Double doping & {$[131]$} \\
\hline \multirow[t]{4}{*}{ Cellulose-based nanocomposites } & \multirow[t]{2}{*}{ Physical } & Wet process & {$[132-134]$} \\
\hline & & Dry process & {$[100,135]$} \\
\hline & \multirow[t]{2}{*}{ Chemical } & In situ chemical reduction method & {$[136-138]$} \\
\hline & & Covalent bonding & {$[100,139]$} \\
\hline \multirow[t]{11}{*}{ Chitosan-based nanocomposites } & \multirow[t]{3}{*}{ Physical } & Thermal method & {$[102-104]$} \\
\hline & & Gamma-ray irradiation & {$[140]$} \\
\hline & & Ultraviolet irradiation & {$[101,141]$} \\
\hline & \multirow[t]{6}{*}{ Chemical } & One-step desolvation & {$[142]$} \\
\hline & & In situ chemical method & {$[107,143,144]$} \\
\hline & & Ex situ chemical method & {$[108,145]$} \\
\hline & & Layer-by-layer approach & {$[146]$} \\
\hline & & Solution casting & {$[110]$} \\
\hline & & Three-step procedure & {$[147]$} \\
\hline & \multirow[t]{2}{*}{ Biological } & Dual purpose strategy & [116] \\
\hline & & Green electrochemical procedure & {$[148]$} \\
\hline
\end{tabular}

including averting aggregation, enabling definitive size regulation, and advancing the biological compatibility of the resulting nanocomposites, amongst others [99].

The in situ chemical reduction approach has also been employed to fabricate silver nanoparticle-cellulose composites [100]. Further, this method has been reported to synthesize silver nanoparticle-chitosan composites by employing specific reducing and metal precursor agents, i.e., sodium borohydride and silver nitrate, respectively [107]. In this method, the choice of stabilizer, reducing agent, and processing conditions are identified to affect the size range of the fabricated silver nanocomposites [101]. In addition to the 'in situ' strategies, several ex situ chemical techniques have also been reported for the synthesis of silver nanoparticle-chitosan composites [108]. Ghosh et al. reported a layer-by-layer manufacturing strategy, who dumped a hybrid chitosan/silver thin coating onto a stainless steel and quartz band [109]. Similarly, a solution casting approach has been reported by Tripathi et al. to develop a film comprising of silver oxide-chitosan nanocomposites, where the silver ions, from a nitrate solution, whereas reduced using sodium citrate [110]. It can be noted that the chemical approach for silver nanocomposite synthesis requires toxic chemicals, which may affect their biological properties. 


\section{Biological approach}

Past studies have reported the development of hybrid silver nanocomposites with the nanoparticles primarily being synthesized using green approaches, such as ultrasound, microwave, sunlight, or biomolecules. Most of these synthesis strategies are guided based on the functionalization of nanoparticles with biomolecules to form nanocomposites [111]. Graphene-silver nanoparticle composites have been fabricated in which the graphene isolation was achieved based on the alterations of the Hummers method [112]. However, concerns regarding ecological toxicity provide adverse implications for these efforts [111]. Improving on this front, graphene/silver nanocomposites were reported to be manufactured using an eco-friendly stabilizing and reducing agent in the form of sodium citrate [113]. Although, as noted above, considerable discussions and dilemmas exist in the literature regarding their unanimous acceptance, citing certain degrees of adverse environmental repercussions. These traditional approaches have been countered recently using methods that fabricate graphene-functionalized silver nanocomposites, mediated by the employment of phytosynthesized AgNPs $[111,114]$. These studies highlight an effective way to bypass the Hummers method and being more environmentally amenable in the process. The applicability of the green or biological approach has been extended to the synthesis of silver-graphene nanocomposites, mainly attributing to their propensity towards reduced adulteration via hazardous substances, ecological amenability, and healthpromoting aspects [115]. Further, chitosan nanocomposites with incorporated AgNPs have been produced using a green approach via a naturally occurring biopolymer that serves a dual purpose by acting both as a stabilizer and a reducing agent [116]. However, the stability of the nanocomposites is a major concern in the biological synthesis approach, which eventually reduces their significant characteristics. Thus, a balance of stability, toxicity, cost, reaction time and significant biological properties must be taken into consideration, during the selection of synthesis approach for biomedical applications.

\section{Antiviral activity of AgNPs and nanocomposites}

AgNPs fabricated from any approach have been known for their antimicrobial property against bacteria, fungi, and viruses [20, 149]. Silver nanoparticles possess the ability to continuously release silver ions that can bind with the cell wall and cytoplasmic membrane of microbes via electrostatic attraction and sulfur affinity proteins, leading to damage and inhibition of microbes via deactivation of respiratory enzymes, reactive oxygen species generation, and adenosine triphosphate interruption [150-152]. Even though this microbial inhibition mechanism of silver nanoparticles is proposed in various research studies, their exact antimicrobial mechanism has not been entirely clarified until now [153-155]. Recently, AgNPs have been widely employed as a potential antiviral agent due to their broad-spectrum antimicrobial properties, compared to bulk silver materials, microparticles of silver, standalone silver ions, and other metal nanoparticles [156, 157]. Thus, AgNPs are fabricated via physical, chemical, and biological approaches to possess unique properties for inhibiting targeted pathogenic viruses $[158,159]$, which makes them to be incorporated in commercial products, such as disinfection agents and paints [160-162]. Numerous researchers have studied the antiviral efficacy of AgNPs against several viruses, regardless of the specific family, such as human immunodeficiency virus (HIV), hepatitis B virus (HBV), H3N2 influenza virus, herpes simplex virus (HSV) types 1 and 2, influenza A (IFV-A), human parainfluenza virus type 3 , bean yellow mosaic virus (BYMV), and few others as tabulated in Table 3.

\section{Antiviral activity of physically synthesized AgNPs and nanocomposites}

The antiviral potential of mercaptoethane sulfonate-protected AgNPs (Ag-MES) synthesized by the sonochemical reaction was tested against HSV-1 [163]. The HSV internalizes into the host cells when the extracellular virions are attached via glycoprotein to the cell's surface. Later, the glycoprotein interacts with cellular heparan sulfate (HS) individually during the attachment phase. It has been reported that the Ag-MES nanoparticles can limit the viralhost interaction by mimicking HS on the host cell membrane to block the viral attachment. Likewise, Du et al. fabricated glutathione capped silver sulfide nanoparticles (GO-AgNPs) nanocomposites by using an electrostatic selfassembly technique. The antiviral activity of GO-AgNPs nanocomposites was investigated against the porcine reproductive and respiratory syndrome virus (PRRSV) and porcine epidemic diarrhea virus (PEDV). Their results showed that GO-AgNPs nanocomposites suppressed PRRSV and PEDV infection by down-regulating the PRRSV and PEDV nucleocapsid protein expression level, thus reducing virus replication. Besides, they also identified that GO-AgNPs nanocomposites prevent PRRSV and PEDV from entering the host cells. Moreover, GO-AgNPs nanocomposite also inhibited the proliferation of the virus by enhancing the production of interferon- $\alpha$ (IFN- $\alpha$ ) and IFN-stimulating genes (ISGs) [164]. Recently, Castro-Mayorga et al. used the electrospinning technique to synthesize the poly (3-hydroxybutyrate-co-3mol\%-3-hydroxyvalerate) fibers coated with AgNPs (PHBV3/AgNPs). The efficacy of PHBV3/AgNPs in inhibiting norovirus surrogates, the feline calicivirus (FCV), 


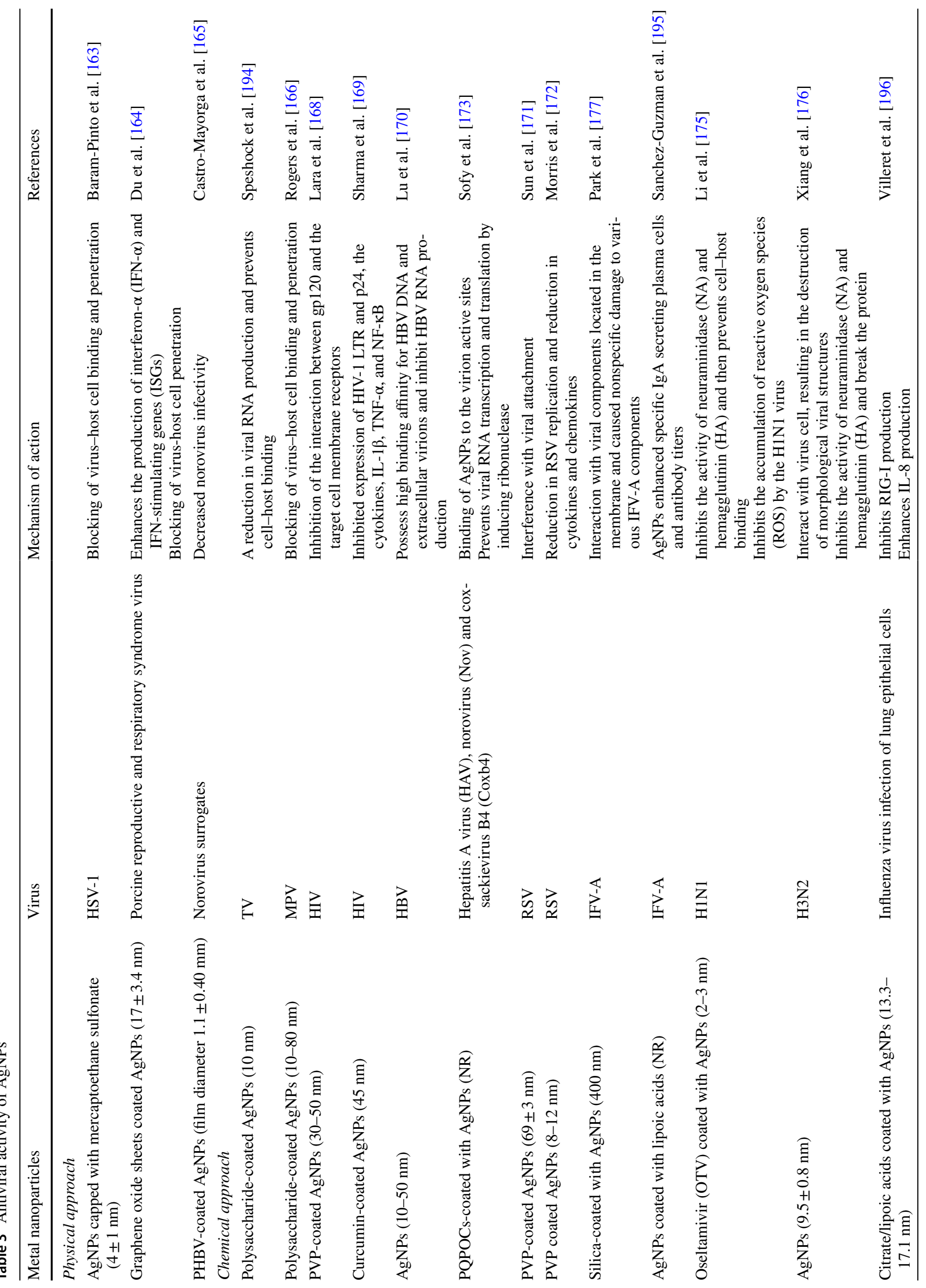




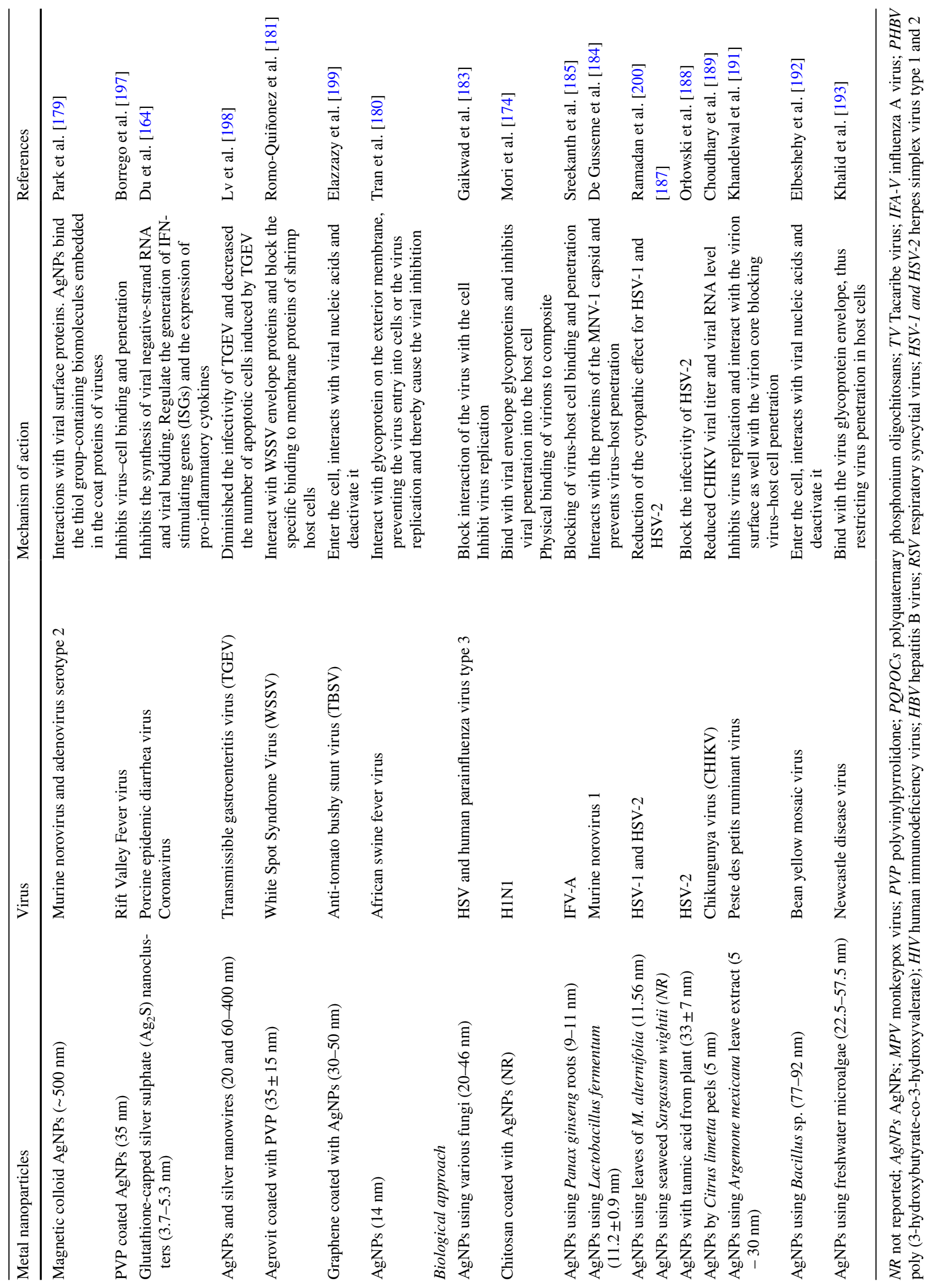


and the murine norovirus (MNV) were determined to have a film diameter of $1.1 \pm 0.40 \mathrm{~mm}$. Further, the PHBV3/AgNPs were inoculated with norovirus surrogates, and their results showed that FCV and MNV titers decreased significantly, which represents the reduction of norovirus infectivity [165].

\section{Antiviral activity of chemically synthesized AgNPs and nanocomposites}

The antiviral activity of polysaccharide coated AgNPs (PS-AgNPs) with sizes 10-80 $\mathrm{nm}$ was tested against the monkeypox virus by Rogers et al. [166]. The results showed that the PS-AgNPs with a size of $10 \mathrm{~nm}$ possessed the highest efficacy, as confirmed by a reduction in MPV plaque formation. The mechanism of viral inhibition may involve AgNPs preventing virus-host cell binding and/or interruption of host cell biochemical pathways. Similarly, Speshock et al. synthesized the PS-AgNPs through the chemical reduction method, and its antiviral efficacy was tested against Tacaribe virus (TCRV). The study identified that the AgNPs can inhibit the virus by binding with their glycoproteins. Besides, they also deduced that there is a strong interaction between the TCRV and AgNPs, as there are several cysteines located at the TCRV glycoproteins. Thiol groups were also found in cysteine residues, and AgNPs showed a high affinity to thiol groups. Therefore, this interaction was confirmed to prevent the virus's internalization via inhibition of glycoprotein-receptor interactions and/or interrupts the viral replication within the cell post-entry. Moreover, inhibition of virus RNA (vRNA) was observed in this study, which indicated that AgNps could be interrupting the synthesis of TCRV RNA-dependent RNA polymerase (L protein), hence preventing viral replication [167].

The antiviral activity of PVP-coated AgNPs was also tested against HIV, and its mode of action was identified to be its ability to block the interaction between the virus glycoprotein named gp120 and the host cell [168]. Besides, the study deduced that the AgNPs might interact with gp120 glycoprotein and alter viral protein by modifying the disulfide-bonded domain present in the CD4 binding region. Remarkably, the antiviral activity of curcumin (Cur) coated AgNPs was also investigated by Sharma et al. (2017). Further, Cur-AgNPs were used to treat HIV-infected cells. Their results showed that HIV-1 LTR gene expression and HIV-1 p24 levels were greatly inhibited and proved that Cur-AgNPs have significant anti-HIV therapeutic potential. Also, the infected cells treated with Cur-AgNPs showed a substantial reduction in the gene expression of pro-inflammatory cytokines such as IL- 6 , TNF- $\alpha$, and IL- $1 \beta$. Furthermore, they also observed a substantial decrease in NFkB gene expression [169]. Moreover, AgNPs with size ranging from 10-80 nm was used to treat HBV [170]. Their results showed that AgNPs with $10 \mathrm{~nm}$ could effectively prevent the replication of HBV DNA. The study hypothesized that AgNPs impede the transcription of viral RNA by binding directly or interacting with HBV DNA, which serves as the template for RNA synthesis and subsequently decreases the number of extracellular virions. Additionally, Sun et al. (2008) and Morris et al. (2019) investigated the mode of actions of PVP coated AgNPs in treating infection caused by RSV [171, 172]. Both authors concluded that the inhibition of RSV was linked to the attachment of AgNPs to surface glycoproteins, restricting the ability of RSV to initiate the attachment with a receptor, preventing the virus-cell penetration. Also, AgNPs significantly reduced RSV replication and pro-inflammatory cytokines as well as chemokines [171, 172].

A new novel PQPOCs coated with AgNPs was synthesized by Sofy et al. (2019). It was deduced from this study that PQPOCs-AgNPs displayed stronger antiviral activity against norovirus (Nov), hepatitis A virus (HAV), and coxsackievirus B4 (Coxb4) when compared with only PQPOCs. The improved antiviral potential of PQPOCs-AgNPs could be linked to the properties of AgNPs enhancing molecular interactions with viral glycoproteins and blocking viral penetration [173, 174]. Consequently, it was presumed that PQPOC acted as a viral interior inhibitor and blocked viruses' interaction with the host cells. Further, Li et al. investigated the antiviral activity of oseltamivir (OTV) coated with AgNPs against H1N1 influenza [175], while Xiang et al. used AgNPs against H3N2 influenza [176]. Both Ag-OTV nanoparticles and AgNPs bind tightly to the hemagglutinin (HA) protein and neuraminidase (NA), which prevents the virus's attachment with the host cells. Besides, Ag-OTV nanoparticles and AgNPs prevent DNA fragmentation, chromatin condensation, and the activity of caspase-3, which is a significant mediator of cell apoptosis. Notably, Park et al. investigated microscale silica-coated silver composites' inhibition mechanism against IFV-A. Due to the microscale size of $\mathrm{SiO}_{2}$, the primary interactions between $\mathrm{Ag}-\mathrm{SiO}_{2}$ particles were restricted to the outermost layer of a viral membrane instead of the inner viral components. Additionally, they illuminated the exposure of $\mathrm{Ag}-\mathrm{SiO}_{2}$ particles to IFV-A, which could damage the HA and NA that are located in the outer membrane of IFV-A and this proved that $\mathrm{Ag}-\mathrm{SiO}_{2}$ as major targets could be located at the surfaces of virus [177].

Villeret et al. studied the efficacy of citrate/lipoic acids coated with AgNPs against influenza virus infection of lung epithelial cells. The results indicated that AgNPs reduced the release of influenza induced cytokines such as CCL-5 and IFN- $\beta$ through RIG-I inhibition. Moreover, AgNPs also enhanced the production of a cytokine beneficial for mobilizing host antibacterial responses via IL-8. Notably, AgNPs activity was independent of the coating process and depends only on the silver core [178]. Further, 
Park et al. evaluated the effectiveness of AgNPs magnetic hybrid colloids (AgNPMHCs) for inactivating murine norovirus (MNV) and adenovirus serotype 2 (AdV2). As AgNPs-MHCs were larger (about $500 \mathrm{~nm}$ ), the study suggested that AgNPs-MHCs cannot penetrate a virus cell. Instead, AgNPs-MHCs were found to interact with viral surface proteins. The AgNPs on the composites are identified to effectively bind with the thiol group-containing glycoproteins surrounding coat proteins of viruses, preventing viruses' entry to host cells. Interestingly, the results obtained showed that the MNV was vulnerable to AgNPs-MHCs, however, AdV2 was unaffected. The study hypothesised that the high resistance level of AdV2 toward AgNPs-MHCs is most likely associated with the size and morphology of the virus [179].

Recently, a disinfectant solution was developed using AgNPs to effectively prevent the transmission of the African swine fever virus in the pig house [180]. Further, Argovit-4 is a silver nanoparticle-based formulation developed by Romo-Quiñonez et al., which demonstrated efficacy against the white spot syndrome virus (WSSV) in shrimp culture. This result also proved that AgNPs are a superior antiviral additive in feed for shrimp aquaculture [181]. Furthermore, chemical synthesized AgNPs and/or nanocomposites were also used to treat other plant and animal viruses, such as Rift valley fever virus, porcine epidemic diarrhea virus coronavirus, transmissible gastroenteritis virus, and anti-tomato bushy stunt virus as summarized in Table 3 . It is worthy to note that the most common mode of action of AgNPs and their associated composites toward all the viruses are the inhibition of virus-cell attachment, penetration of AgNPs into the cell, and disruption of the viral infective groups.

\section{Antiviral activity of biologically synthesized AgNPs}

A novel environmental friendly, biological synthesis method was reported by Mori et al., where AgNPs were obtained by autoclaving commercially available glass powders, which contains silver nitrate and glucose as a reducing agent [182]. Depending on the glucose concentration, the nanoparticles' size can be easily manipulated, and a nanoparticle size of $5 \pm 1 \mathrm{~nm}$ can be proficiently synthesized, whereas no harmful material was found to be generated in the synthesis method. Thus, Mori et al. synthesized these AgNPs coated with chitosan, and their antiviral activity was investigated against H1N1. The results indicated that the inhibition effect was significant with smaller AgNPs in the composites, while no antiviral activity was observed using only pure chitosan. Further, it is deduced that the antiviral activity of this nanocomposite is due to the binding of AgNPs with the glycoproteins of the virus and subsequently inhibiting virus-host cell penetration. Besides, the physical binding of extracellular virions to the chitosan composites could instantly hinder viral contact with host cells [174]. Likewise, Gaikwad et al. (2013), De Gusseme et al. (2010) and Sreekanth et al. (2018) biologically synthesized AgNPs using plant extracts, bacteria, and fungi, respectively. The average size of AgNPs was in the range of 9 to $46 \mathrm{~nm}$. The antiviral activity of these nanoparticles was tested against viruses such as HSV, human parainfluenza virus type 3 , murine norovirus 1 , and IFV-A. It can be noted that these AgNPs caused the inactivation of the viruses by blocking the virus-cell interaction and preventing the entry of the virus into the host cell [183-185]. Further, the AgNPs also inhibited virus replication, thus reduced the viral titer. Remarkably, Ramadan et al. (2019), Dhanasezhian et al. (2019) and Orłowski et al. (2018) produced AgNPs using plant extracts and their efficacy to inhibit HSV-1 and HSV-2 was investigated. The results elucidated that the smaller sized AgNPs can effectively reduce the cytopathic effect of HSV-1 and HSV-2, and thus blocked the infectivity of these viruses [186-188]. Furthermore, Choudhary et al. synthesized $\sim 5 \mathrm{~nm}$-sized AgNPs via extracts from Citrus limetta peels, and its antiviral activity was evaluated against the Chikungunya virus (CHIKV). The results showed that the AgNPs significantly reduced the CHIKV viral titer by inhibiting the viral RNA synthesis [189]. The potential of nano-silver in treating viral infections and related oncogenic herpesvirus related cancers were also demonstrated in recent time [190]. More importantly, AgNPs inhibited the Kaposi's sarcoma-associated herpesvirus (KSHV), blocked the primary infection, and moderately suppressed the growth of KSHV associated tumors. Nevertheless, plant extracts, bacteria, and freshwater microalgae were also employed for the biogenic synthesis of AgNPs [191-193]. The antiviral property of these AgNPs is evaluated against various animal or plant viruses, such as "Peste des petits ruminant virus" (a Morbillivirus group member), Bean yellow mosaic virus, and Newcastle disease virus as listed in Table 3. The results of all these studies showed that the AgNPs synthesized via biological approach can inhibit viral replication, bind with the virus glycoprotein, restrict virus-host penetration, interact with the viral nucleic acids and deactivating them with no/less toxicity, compared to physical and chemical synthesized AgNPs.

\section{Advantages and limitations of AgNPs synthesis with antiviral property}

The synthesis approaches determine three significant aspects; functional group, toxicity, and surface charge of the resultant nanoparticles, which eventually affect their properties [201]. It is worthy to note that the antiviral property of nanoparticles is based on their functional groups. The synthesis approach's selection is highly essential to fabricate nanosized particles to inhibit the multiplication of 
pathogenic viruses [202]. The physical approaches are generally used to blend AgNPs with another material to form composites or coat them on the substrate [203]. Even though high energy is required to blend or coat AgNPs, certain chemical agents are required to create strong bonds between the coating surface or with the substrate. These chemical reagents are often toxic and exist as a functional group on AgNPs or nanocomposites' surfaces. For instance, physical methods such as sonochemical, electrostatic self-assembly, and electrospinning approaches are used to fabricate silver nanocomposites to exhibit antiviral activity, as mentioned in the "Antiviral activity of physically synthesized AgNPs and nanocomposites" section. Capping agents such as mercaptoethane sulfonate, sulfur, hydrazine hydrate, and polyhydroxyalkanoates are used in physical methods and display as functional groups on the surface of AgNPs. In addition to inhibiting the protein capsid of viruses and denaturing them, the capping agents are toxic to normal healthy cells when present in concentrations above threshold levels [204-206].

Chemical synthesis usually utilizes chemicals as reducing and stabilizing agents. These include trisodium citrate, sodium borohydride, Tollen's reagent, and N, N-dimethylformamide (DMF) [75]. Unlike the physical approach which uses mechanical energy to stabilize nanoparticles and avoid agglomeration, the chemical approach depends on chemicals and catalysts to avoid agglomeration by acting as a capping agent to stabilize them [207]. These capping agents serve as a functional group to bind with viral surface protein capsid and inhibit them. Further, these functional groups provide surface charge to the synthesized nanoparticles and direct them towards the viral capsid or targeted cell via electrostatic force of attraction [208]. The surface charge and functional group play a significant role in the antiviral activity and cytotoxicity of nanoparticles. Several studies have also indicated that the surface charge of the nanoparticles is crucial in exhibiting cytotoxicity towards normal cells, affecting their ability to inhibit viruses preferentially [209, 210]. Thus, chemically synthesized AgNPs may also lead to adverse effects on the host cells apart from exhibiting antiviral effects.

Biological approaches, introduced as an alternative to chemical and physical methods, involve biomolecules extracted from microbes and plants for enhanced antiviral efficacy [183]. These biomolecules replace toxic chemicals as reducing, stabilizing, and capping agents providing biocompatibility to the synthesized AgNPs [209]. Moreover, the biomolecules act as a surface active functional group that can serve as a potential ligand to dock with the viruses' receptors exhibiting antiviral activity along with AgNPs [210]. For instance, 9-11 nm-sized AgNPs synthesized via Panex ginseng $(P$. ginseng) root extract exhibited antiviral activity against influenza IFV-A virus. It is worthy to note that the smaller sized nanoparticles can enter inside the virus
( 80-120 nm in size) and inhibit their genome. Further, the nanoparticles can bind with the viral capsid and disrupt them via electrostatic attraction mediated by the phytochemicals of $P$. ginseng extract [185]. Furthermore, $P$. ginseng's phytochemicals also possess antiviral efficacy to disrupt the viral capsid [211,212]. Thus, the combinatorial synergistic effect of both AgNPs and the phytochemicals as functional groups are proven to elevate the antiviral efficacy against a broad spectrum of viruses and reduce toxicity, compared to physical and chemical synthesized nanoparticles. Hence, the biological method is highly beneficial to fabricate silver nanoparticles and nanocomposites with effective antiviral properties. However, the long-term stability and yield are the major limitations that must be overcome for large-scale biogenic AgNPs production.

\section{Mechanism of antiviral activity of AgNPs and nanocomposites: synthesis perspective}

The exact mechanism of silver nanoparticles to inhibit microbes, particularly against viruses, is still under research investigations. As proposed in various reported studies, the most common mode of action in inhibiting viruses by silver nanoparticles is binding antiviral agents to the virus coat proteins and interrupting structure and/or function [168]. The mechanism can be classified based on the synthesis approaches of AgNPs, such as physicochemical and biogenic methods. The resultant nanoparticle from both approaches binds with the viral protein's surface and disrupts them [213]. This approach avoids the transmission of the virus in the host cell in the early stage and is highly beneficial in controlling the spread of viral-mediated infection [214]. However, the response of the AgNPs will differ when the virus has infected and invaded the host cells. The physical and chemically synthesized AgNPs bind to the host cell and virus via chemical functional groups, which act as stabilizing or capping agents to avoid agglomeration and improve stability [215, 216]. As they are from a synthetic origin (refer to "Advantages and limitations of AgNPs synthesis with antiviral property" section), these functional groups exhibit inhibitory activity towards viruses and disrupt their viral capsid protein. Further, the nanoparticle disintegrates into silver ions, releases reactive oxygen species, increases oxidative stress, and facilitates virus inhibition [172]. In addition, the silver nanoparticle directly binds with the viral genome, disrupts their structure, and halts their proliferation in the host body [217]. Notably, the biogenic synthesized silver nanoparticle follows the same mechanism when a virus infects a host cell [218]. However, the chemical-based functional group in the AgNPs fabricated via physical or chemical approach can be toxic towards the infected host cell [219]. In fact, toxic functional groups may lead to side 
effects in the host cells, reducing or halting their metabolic activity, causing severe cytotoxicity complications towards the virus-infected host cells [220]. Also, it has been reported in certain studies that chemical synthesized AgNPs are toxic towards the brain and liver cells of rats, depending on the dose, concentration, and type of chemical functional group [221-223]. In the case of biogenic AgNPs, the biomolecules act as a functional group that facilitates the entry of AgNPs into the virus-infected host cells, which improves their biocompatibility [224]. Further, the biomolecules also possess antiviral efficacy, which provides a synergistic inhibitory effect towards viral infection and protects the host cells [225, 226]. Moreover, the biomolecules may serve as nutrients for cell growth or stimulate the host cell immunity, which is highly beneficial in combating viral infections [227]. Thus, the previous scientific investigations emphasized that the biogenic synthesis approach is highly useful for the fabrication of antiviral AgNPs.

\section{Future perspectives}

The antiviral activity of metal nanoparticles, especially AgNPs, showed a strong dependence on particle size as well as morphology, which was supported by experimental studies against viruses, such as HIV-1, HBV, and monkeypox virus [228]. These nanosized silver particles may have been beneficial as a potential antiviral agent due to the size of a virus being in the nano-regime $(100 \mathrm{~nm})$. Thus, $10 \mathrm{~nm}$-sized AgNPs are recommended for antiviral applications to interact effectively with the virus [167]. Currently, $10 \mathrm{~nm}$ sized, monodispersed, and stable AgNPs can be prepared via physical and chemical approaches. However, the resulting nanoparticles possess non-specific toxicity and can affect the host cells, as discussed in "Advantages and limitations of AgNPs synthesis with antiviral property" and "Mechanism of antiviral activity of AgNPs and nanocomposites: synthesis perspective" sections. Hence, hybrid synthesis approaches may be explored to balance the toxicity (low) and stability (high) properties of AgNPs. Moreover, the silver nanoparticles and nanocomposites are currently recommended by several researchers as a potential antiviral agent to combat coronaviruses [18, 229-231], which can lead to severe acute respiratory syndrome coronavirus (SARS-CoV), Middle East respiratory syndrome coronavirus (MERS-CoV), severe acute respiratory syndrome coronavirus-2 (SARS-CoV-2). These new type of viruses can cause acute respiratory distress syndrome (ARDS) and acute lung injury (ALI), which leads to pulmonary failure and/ or fatality [232]. AgNPs have been used to inhibit viruses with pandemic strains, including IFV-A, H1N1, and H3N2, as discussed in "Antiviral activity of biologically synthesized AgNPs" section. The nanoscale AgNPs could inhibit coronavirus by binding with the viral envelope glycoproteins and can inhibit the viral penetration into the host cell and/ or inhibits the activity of neuraminidase (NA) and hemagglutinin (HA) protein. Sarkar investigated and demonstrated the potential of AgNPs as an inhalation delivery agent to suppress SARS-CoV-2 infection, as respiratory infections generally start from the upper respiratory tract [233]. Furthermore, it has been reported that silver nanoparticles can be a potential inorganic antiviral agent to be coated on the surface of textiles and masks for enhanced inhibition of zoonotic and pandemic-causing viruses that may infect humans and cause severe illness [17]. Sportelli et al. also discussed the use of AgNPs for antiviral biomedical applications (e.g. Covid-19 infection) and, more precisely, to halt and limit both infection and contagion [234]. Thus, it is quite evident that AgNPs or nanocomposites synthesized via biological approaches can be highly beneficial as an antiviral agent with the capacity to combat and eliminate various viral infections with reduced toxicity and side effects. Despite the vast potential of nanoparticles in fighting the virus [235], the approval for the nanoparticle-based treatment methods by the Food and Drug Administration (FDA) and the European Medicines Agency (EMA) will be a major hurdle to utilize them for large-scale clinical applications.

\section{Conclusions}

The synthesis approaches affect the size, shape, morphology, and surface charge of the resultant nanoparticle, controlling the antiviral property and cytotoxicity of the silver nanoparticle or nanocomposite. Since these physicochemical parameters facilitate silver nanoparticles' antiviral activity, the selection of synthesis methods is a significant step in preparing an antiviral agent. The limitations of physical and chemical approaches have led to the emergence of biological approaches, as discussed in this work. Even though biological approaches also possess limitations, such as instability and low yield of nanoparticles, they have exhibited promising results in several biomedical applications, including antiviral efficacy against disease-causing viruses. In addition, the functional biomolecules present in the biogenic synthesized AgNPs could lead to a synergistic antiviral efficacy against pathogenic viruses. Thus, it can be concluded that the biogenic or a hybrid (physical and biochemical) synthesis method of silver nanoparticle and nanocomposites could be highly beneficial as a broad-spectrum antiviral agent to inhibit various pathogenic viruses.

Acknowledgements The authors (Dr. Jaison Jeevanandam and Prof. João Rodrigues) acknowledge the support of CQM-Centro de Química da Madeira, University of Madeira and FCT-Fundação para a Ciência e a Tecnologia in the preparation of this manuscript. All the other authors 
would like to thank their respective departments and universities for their support in preparing this manuscript.

Author contributions JJ: conceptualization, writing original draftreviewing and editing; SK: writing original draft; YSH: writing original draft; SP: writing original draft; YSC: writing - reviewing and editing; CA: writing—reviewing and editing; MKD: writing—reviewing and editing; JR: conceptualization, writing-reviewing and editing.

Funding FCT-Fundação para a Ciência e a Tecnologia (Base Fund UIDB/00674/2020 and Programmatic Fund UIDP/00674/2020, Portuguese Government Funds) and ARDITI-Agência Regional para o Desenvolvimento da Investigação Tecnologia e Inovação through the project M1420-01-0145-FEDER-000005-CQM ${ }^{+}$(Madeira 14-20 Program).

Availability of data and material Not applicable.

\section{Declarations}

Conflict of interest No conflict of interest to declare. Creative Carbon Labs Pvt. Ltd. does not produce or sell and does not intend to sell silver nanoparticles for commercial applications.

Ethical approval Not applicable.

Consent to participate Not applicable.

Consent for publication Not applicable.

\section{References}

1. Sharma, G., Kumar, A., Sharma, S., Naushad, M., Dwivedi, R.P., Alothman, Z.A., Mola, G.T.: Novel development of nanoparticles to bimetallic nanoparticles and their composites: a review. J. King Saud Univ. Sci. 31, 257-269 (2019)

2. Li, Q., Liu, F., Li, M., Chen, C., Gadd, G.M.: Nanoparticle and nanomineral production by fungi. Fung. Biol. Rev. (2021)

3. Jeevanandam, J.K., Danquah, M., Debnath, S., Meka, V., Chan, Y.: Opportunities for nano-formulations in type 2 diabetes mellitus treatments. Curr. Pharm. Biotechnol. 16, 853-870 (2015)

4. Rehman, S., Asiri, S.M., Khan, F.A., Jermy, B.R., Khan, H., Akhtar, S., Jindan, R.A., Khan, K.M., Qurashi, A.: Biocompatible tin oxide nanoparticles: synthesis, antibacterial, anticandidal and cytotoxic activities. Chem. Sel. 4, 4013-4017 (2019)

5. Ghodrati, M., Mir, A., Farmani, A.: Non-destructive label-free biomaterials detection using tunneling carbon nanotube-based biosensor. IEEE Sens. J. 21, 8847-8854 (2021)

6. Pareek, V., Bhargava, A., Gupta, R., Jain, N., Panwar, J.: Synthesis and applications of noble metal nanoparticles: a review. Adv. Sci. Eng. Med. 9, 527-544 (2017)

7. Rehman, S., Asiri, S.M., Khan, F.A., Jermy, B.R., Ravinayagam, V., Alsalem, Z., Jindan, R.A., Qurashi, A.: Anticandidal and in vitro anti-proliferative activity of sonochemically synthesized indium tin oxide nanoparticles. Sci. Rep. 10, 3228 (2020)

8. Kalimuthu, K., Cha, B.S., Kim, S., Park, K.S.: Eco-friendly synthesis and biomedical applications of gold nanoparticles: a review. Microchem. J. 152, 104296 (2020)

9. Hussein, H.A., Abdullah, M.A.: Functional bionanomaterials, pp. 313-332. Springer, New York (2020)

10. Burdușel, A.-C., Gherasim, O., Grumezescu, A.M., Mogoantă, L., Ficai, A., Andronescu, E.: Biomedical applications of silver nanoparticles: an up-to-date overview. Nanomaterials 8, 681 (2018)

11. Behera, S., Debata, A.: Biomedical applications of silver nanoparticles. J. Asian Sci. Res. 1, 27 (2011)

12. Ahmed, S., Ahmad, M., Swami, B.L., Ikram, S.: A review on plants extract mediated synthesis of silver nanoparticles for antimicrobial applications: a green expertise. J. Adv. Res. 7, 17-28 (2016)

13. Hillenkamp, M., Di Domenicantonio, G., Eugster, O., Félix, C.: Instability of $\mathrm{Ag}$ nanoparticles in $\mathrm{SiO}_{2}$ at ambient conditions. Nanotechnology 18, 015702 (2006)

14. Travan, A., Marsich, E., Donati, I., Paoletti, S.: Silver nanocomposites and their biomedical applications. Wiley-VCH, Weinheim (2010)

15. Patra, J.K., Baek, K.-H.: Green nanobiotechnology: factors affecting synthesis and characterization techniques. J. Nanomater. 2014, 219 (2014)

16. Jeevanandam, J., Pal, K., Danquah, M.K.: Virus-like nanoparticles as a novel delivery tool in gene therapy. Biochimie 157, 38-47 (2019)

17. Imani, S.M., Ladouceur, L., Marshall, T., Maclachlan, R., Soleymani, L., Didar, T.F.: Antimicrobial nanomaterials and coatings: current mechanisms and future perspectives to control the spread of viruses including SARS-CoV-2. ACS Nano 14, 12341-12369 (2020)

18. Al-Sanea, M.M., Abelyan, N., Abdelgawad, M.A., Musa, A., Ghoneim, M.M., Al-Warhi, T., Aljaeed, N., Alotaibi, O.J., Alnusaire, T.S., Abdelwahab, S.F.: Strawberry and ginger silver nanoparticles as potential inhibitors for SARS-CoV-2 assisted by in silico modeling and metabolic profiling. Antibiotics 10, 824 (2021)

19. Parveen, K., Banse, V., Ledwani, L.: Green synthesis of nanoparticles: their advantages and disadvantages. AIP conf. proceed. 1724, p. 020048 (2016)

20. Chernousova, S., Epple, M.: Silver as antibacterial agent: ion, nanoparticle, and metal. Angew. Chem. Int. Ed. 52, 1636-1653 (2013)

21. Parameswaranpillai, J., Hameed, N., Kurian, T., Yu, Y.: Nanocomposite materials: synthesis, properties and applications. CRC Press, Boca Raton (2016)

22. Vollath, D.: An introduction to synthesis, properties and application. Management 7, 865-870 (2008)

23. Nahar, M., Dutta, T., Murugesan, S., Asthana, A., Mishra, D., Rajkumar, V., Tare, M., Saraf, S., Jain, N.K.: Functional polymeric nanoparticles: an efficient and promising tool for active delivery of bioactives. Crit. Rev. Ther. 23, 259-318 (2006)

24. Gloria, E.C., Ederley, V., Gladis, M., César, H., Jaime, O., Oscar, A., José, I.U., Franklin, J.: Synthesis of silver nanoparticles (AgNPs) with antibacterial activity. J. Phys. Conf. Ser. 850, 012023 (2017)

25. Rekha, C.R., Nayar, V.U., Gopchandran, K.G.: Synthesis of highly stable silver nanorods and their application as SERS substrates. J. Sci. Adv. Mater. Dev. 3, 196-205 (2018)

26. Swarnavalli, G.C.J., Joseph, V., Kannappan, V., Roopsingh, D.: A simple approach to the synthesis of hexagonal-shaped silver nanoplates. J. Nanomater. 2011, 825637 (2011)

27. Wu, F., Wang, W., Xu, Z., Li, F.: Bromide (Br)-based synthesis of Ag nanocubes with high-yield. Sci. Rep. 5, 10772 (2015)

28. Dong, Y., Zhu, H., Shen, Y., Zhang, W., Zhang, L.: Antibacterial activity of silver nanoparticles of different particle size against Vibrio Natriegens. PLoS ONE 14, e0222322 (2019)

29. Xiu, Z.-M., Ma, J., Alvarez, P.J.J.: Differential effect of common ligands and molecular oxygen on antimicrobial activity of silver nanoparticles versus silver ions. Environ. Sci. Technol. 45, 9003-9008 (2011) 
30. Kumar, S.V., Bafana, A.P., Pawar, P., Rahman, A., Dahoumane, S.A., Jeffryes, C.S.: High conversion synthesis of $<10 \mathrm{~nm}$ starchstabilized silver nanoparticles using microwave technology. Sci. Rep. 8, 1-10 (2018)

31. Pal, S., Tak, Y.K., Song, J.M.: Does the antibacterial activity of silver nanoparticles depend on the shape of the nanoparticle? A study of the gram-negative bacterium Escherichia coli. Appl. Environ. Microbiol. 73, 1712-1720 (2007)

32. Morones, J.R., Elechiguerra, J.L., Camacho, A., Holt, K., Kouri, J.B., Ramírez, J.T., Yacaman, M.J.: The bactericidal effect of silver nanoparticles. Nanotechnology 16, 2346 (2005)

33. Jung, J.H., Hwang, G.B., Lee, J.E., Bae, G.N.: Preparation of airborne $\mathrm{Ag} / \mathrm{CNT}$ hybrid nanoparticles using an aerosol process and their application to antimicrobial air filtration. Langmuir 27, 10256-10264 (2011)

34. Balagna, C., Perero, S., Percivalle, E., Nepita, E.V., Ferraris, M.: Virucidal effect against coronavirus SARS-CoV-2 of a silver nanocluster/silica composite sputtered coating. Open Ceram. 1, 100006 (2020)

35. Tian, J., Wong, K.K., Ho, C.M., Lok, C.N., Yu, W.Y., Che, C.M., Chiu, J.F., Tam, P.K.: Topical delivery of silver nanoparticles promotes wound healing. Chem. Med. Chem. 2, 129-136 (2007)

36. Sibbald, R.G., Contreras-Ruiz, J., Coutts, P., Fierheller, M., Rothman, A., Woo, K.: Bacteriology, inflammation, and healing: a study of nanocrystalline silver dressings in chronic venous leg ulcers. Adv. Skin Wound Care 20, 549-558 (2007)

37. Tadele, K.T., Abire, T.O., Feyisa, T.Y.: Green synthesized silver nanoparticles using plant extracts as promising prospect for cancer therapy: a review of recent findings. J. Nanomed. 4, 1040 (2021)

38. Gurunathan, S., Lee, K.-J., Kalishwaralal, K., Sheikpranbabu, S., Vaidyanathan, R., Eom, S.H.: Antiangiogenic properties of silver nanoparticles. Biomaterials 30, 6341-6350 (2009)

39. Asharani, P., Hande, M.P., Valiyaveettil, S.: Anti-proliferative activity of silver nanoparticles. BMC Cell Biol. 10, 65 (2009)

40. Makvandi, P., Nikfarjam, N., Sanjani, N.S., Qazvini, N.T.: Effect of silver nanoparticle on the properties of poly (methyl methacrylate) nanocomposite network made by in situ photoinifertermediated photopolymerization. Bull. Mater. Sci. 38, 1625-1631 (2015)

41. Yong, C., Chen, X., Xiang, Q., Li, Q., Xing, X.: Recyclable magnetite-silver heterodimer nanocomposites with durable antibacterial performance. Bioact. Mater. 3, 80-86 (2018)

42. Chen, Y.-N., Hsueh, Y.-H., Hsieh, C.-T., Tzou, D.-Y., Chang, P.-L.: Antiviral activity of graphene-silver nanocomposites against non-enveloped and enveloped viruses. Int. J. Environ. Res. Public Health 13, 430 (2016)

43. Wiesenmueller, S., Cierniak, P., Juebner, M., Koerner, E., Hegemann, D., Mercer-Chalmers Bender, K.: Tailored antimicrobial activity and long-term cytocompatibility of plasma polymer silver nanocomposites. J. Biomater. Appl. 33, 327-339 (2018)

44. Farahani, M., Farahani, A.: Evaluation of antibacterial properties of resin composites containing silver nanoparticles on Streptococcus mutans. Int. J. Dent. Oral Health 1, 1 (2017)

45. Limaye, M.V., Gupta, V., Singh, S.B., Paik, G.R., Singh, P.: Antimicrobial activity of composite consisting of cellulose nanofibers and silver nanoparticles. Chem. Sel. 4, 12164-12169 (2019)

46. Huang, X., Bao, X., Liu, Y., Wang, Z., Hu, Q.: Catechol-functional chitosan/silver nanoparticle composite as a highly effective antibacterial agent with species-specific mechanisms. Sci. Rep. 7, 1-10 (2017)

47. Dukes, K.D., Christensen, K.A., Chumanov, G.: Core-shell silver nanoparticles for optical labeling of cells. Anal. Biochem. 458, 43-48 (2014)
48. Jeevanandam, J., Sundaramurthy, A., Sharma, V., Murugan, C., Pal, K., Kodous, M.H.A., Danquah, M.K.: Sustainable Nanoscale Engineering, pp. 83-113. Elsevier, Amsterdam (2020)

49. Iravani, S., Korbekandi, H., Mirmohammadi, S.V., Zolfaghari, B.: Synthesis of silver nanoparticles: chemical, physical and biological methods. Res. Pharm. Sci. 9, 385-406 (2014)

50. Lee, S.H., Jun, B.-H.: Silver nanoparticles: synthesis and application for nanomedicine. Int. J. Mol. Sci. 20, 865 (2019)

51. Thanh, N.T.K., Maclean, N., Mahiddine, S.: Mechanisms of nucleation and growth of nanoparticles in solution. Chem. Rev. 114, 7610-7630 (2014)

52. Satyanarayana, T., Reddy, S.: A review on chemical and physical synthesis methods of nanomaterials. Int. J. Res. Appl. Sci. Tech. 6, 2321-9653 (2018)

53. Piras, C.C., Fernández-Prieto, S., De Borggraeve, W.M.: Ball milling: a green technology for the preparation and functionalisation of nanocellulose derivatives. Nano. Adv. 1, 937-947 (2019)

54. Ranu, B., Stolle, A., Cravotto, G., Juaristi, E., Su, W., Lamaty, F., Friscic, T., Mack, J., Takahiro, H., Kraus, G.: Ball Milling Towards Green Synthesis: Applications, Projects, Challenges. Royal Society of Chemistry (2014)

55. Sopicka-Lizer, M.: High-Energy Ball Milling: Mechanochemical Processing of Nanopowders. Elsevier (2010)

56. Serra, P., Duocastella, M., Fernández-Pradas, J.M., Morenza, J.L.: Advances in laser materials processing: technology, research and applications. In: Lawrence, J., Pou, J., Low, D.K.Y., Toyserkani, E. (eds.) Advances in Laser Materials Processing, pp. 367-393. Woodhead Publishing, Cambridge (2010)

57. Russo, R.E., Mao, X., Gonzalez, J.J., Zorba, V., Yoo, J.: Laser ablation in analytical chemistry. Anal. Chem. 85, 6162-6177 (2013)

58. Sportelli, M.C., Izzi, M., Volpe, A., Clemente, M., Picca, R.A., Ancona, A., Lugarà, P.M., Palazzo, G., Cioffi, N.: The pros and cons of the use of laser ablation synthesis for the production of silver nano-antimicrobials. Antibiotics 7, 67 (2018)

59. Jose Varghese, R., Sakho, E.H.M., Parani, S., Thomas, S., Oluwafemi, O.S., Wu, J.: In: Thomas, S., Sakho, E.H.M., Kalarikkal, N., Oluwafemi, S.O., Wu, J. (eds.) Nanomaterials for Solar Cell Applications, pp. 75-95. Elsevier, Amsterdam (2019)

60. Dahlin, R.L., Kasper, F.K., Mikos, A.G.: Polymeric nanofibers in tissue engineering. Tissue Eng. B Rev. 17, 349-364 (2011)

61. Pant, B., Park, M., Park, S.-J.: One-Step Synthesis of silver nanoparticles embedded polyurethane nano-fiber/net structured membrane as an effective antibacterial medium. Polymers 11, 1185 (2019)

62. Abareshi, M., Shahroodi, S.M.: Effects of silver nanoparticles on the thermal properties of polyethylene matrix nanocomposites. J. Therm. Anal. Calorim. 128, 1117-1124 (2017)

63. Raffi, M., Rumaiz, A.K., Hasan, M.M., Shah, S.I.: Studies of the growth parameters for silver nanoparticle synthesis by inert gas condensation. J. Mater. Res. 22, 3378-3384 (2007)

64. Asanithi, P., Chaiyakun, S., Limsuwan, P.: Growth of silver nanoparticles by DC magnetron sputtering. J. Nanomater. 2012, 963609 (2012)

65. Ribeiro, A.I., Senturk, D., Silva, K.S., Modic, M., Cvelbar, U., Dinescu, G., Mitu, B., Nikiforov, A., Leys, C., Kuchakova, I., Vanneste, M., Heyse, P., De Vrieze, M., Souto, A.P., Zille, A.: Efficient silver nanoparticles deposition method on DBD plasmatreated polyamide 6,6 for antimicrobial textiles. IOP Conf. Ser. Mater. Sci. Eng. 460, 012007 (2018)

66. Wu, Z., Cai, J., Wang, J., Geng, Z., Wang, Q.: Low-temperature $\mathrm{Cu}-\mathrm{Cu}$ bonding using silver nanoparticles fabricated by physical vapor deposition. J. Electron. Mater. 47, 988-993 (2018)

67. Neacşu, I.A., Nicoară, A.I., Vasile, O.R., Vasile, B.Ş: Inorganic micro- and nanostructured implants for tissue engineering. In: Grumezescu, A.M. (ed.) Nanobiomaterials in Hard Tissue 
Engineering, pp. 271-295. William Andrew Publishing, Norwich (2016)

68. Barry, C., Grant, N.: In: Carter, C.B., Norton, M.G. (eds.) Ceramic Materials: Science and Engineering, pp. 400-411. Springer, New York (2007)

69. Bensebaa, F.: In: Bensebaa, F. (ed.) Interface Science and Technology, pp. 85-146. Elsevier, Amsterdam (2013)

70. Rao, B.G., Mukherjee, D., Reddy, B.M.: In: Ficai, D., Grumezescu, A.M. (eds.) Nanostructures for Novel Therapy, pp. 1-36. Elsevier, Amsterdam (2017)

71. Dong, H., Chen, Y.C., Feldmann, C.: Polyol synthesis of nanoparticles: status and options regarding metals, oxides, chalcogenides, and non-metal elements. Green Chem. 17, 4107-4132 (2015)

72. Xu, Q.-T., Li, J.-C., Xue, H.-G., Guo, S.-P.: Binary iron sulfides as anode materials for rechargeable batteries: crystal structures, syntheses, and electrochemical performance. J. Power Sources 379, 41-52 (2018)

73. Asim, N., Ahmadi, S., Alghoul, M.A., Hammadi, F.Y., Saeedfar, K., Sopian, K.: Research and development aspects on chemical preparation techniques of photoanodes for dye sensitized solar cells. Int. J. Photoenergy 2014, 21 (2014)

74. Sharma, P., Lotey, G.S., Singh, S., Verma, N.K.: Solution-combustion: the versatile route to synthesize silver nanoparticles. J. Nanopart. Res. 13, 2553-2561 (2011)

75. Guzmán, M.G., Dille, J., Godet, S.: Synthesis of silver nanoparticles by chemical reduction method and their antibacterial activity. Int. J. Chem. Biomol. Eng. 2, 104-111 (2009)

76. Starowicz, M., Stypuła, B., Banaś, J.: Electrochemical synthesis of silver nanoparticles. Electrochem. Commun. 8, 227-230 (2006)

77. Biresaw, S.S., Damte, S.M., Taneja, P.: Green synthesized silver nanoparticles: a promising anticancer agent. Int. J. Nanosci. 19, 1950027 (2020)

78. Mohsen, W., Sadek, M.A., Elazab, H.A.: Green synthesis of copper oxide nanoparticles in aqueous medium as a potential efficient catalyst for catalysis applications. Int. J. Appl. Eng. Res. 12, 14927-14930 (2017)

79. Fayaz, M., Tiwary, C.S., Kalaichelvan, P.T., Venkatesan, R.: Blue orange light emission from biogenic synthesized silver nanoparticles using Trichoderma viride. Colloids Surf. B 75, 175-178 (2010)

80. Javaid, A., Oloketuyi, S.F., Khan, M.M., Khan, F.: Diversity of bacterial synthesis of silver nanoparticles. BioNanoScience $\mathbf{8}$, 43-59 (2018)

81. Anandaradje, A., Meyappan, V., Kumar, I., Sakthivel, N.: Nanoparticles in Medicine, pp. 99-133. Springer, New York (2020)

82. Singh, N., Bhuker, A., Jeevanadam, J.: Effects of metal nanoparticle-mediated treatment on seed quality parameters of different crops. Naunyn-Schmiedeberg's Arch. Pharmacol. 394, 1067-1089 (2021)

83. Ke, M., Li, Y., Qu, Q., Ye, Y., Peijnenburg, W., Zhang, Z., Xu, N., Lu, T., Sun, L., Qian, H.: Offspring toxicity of silver nanoparticles to Arabidopsis thaliana flowering and floral development. J. Hazard. Mater. 386, 121975 (2020)

84. Khan, M.S., Qureshi, N.A., Jabeen, F.: Assessment of toxicity in fresh water fish Labeo rohita treated with silver nanoparticles. Appl. Nanosci. 7, 167-179 (2017)

85. Juan, W., Kunhui, S.H.U., Zhang, L.I., Youbin, S.I.: Effects of silver nanoparticles on soil microbial communities and bacterial nitrification in suburban vegetable soils. Pedosphere 27, 482-490 (2017)

86. Jeevanandam, J., Chan, Y.S., Danquah, M.K.: Biosynthesis of metal and metal oxide nanoparticles. ChemBioEng Rev. 3, 55-67 (2016)
87. Jeevanandam, J., Chan, Y.S., Danquah, M.K.: Biosynthesis and characterization of $\mathrm{MgO}$ nanoparticles from plant extracts via induced molecular nucleation. New J. Chem. 41, 2800-2814 (2017)

88. Ling, J.K.U., Hii, Y.S., Jeevanandam, J., Chan, Y.S., Danquah, M.K.: Phytochemistry: An In-Silico and In-Vitro Update, pp. 315-330. Springer, Singapore (2019)

89. Andra, S., Balu, S.K., Jeevanandham, J., Muthalagu, M., Vidyavathy, M., San Chan, Y., Danquah, M.K.: Phytosynthesized metal oxide nanoparticles for pharmaceutical applications. NaunynSchmiedeberg's Arch. Pharmacol. 392, 755-771 (2019)

90. Agarwal, H., Kumar, S.V., Rajeshkumar, S.: Antidiabetic effect of silver nanoparticles synthesized using lemongrass (Cymbopogon citratus) through conventional heating and microwave irradiation approach. J. Microbiol. Biotechnol. Food Sci. 9, 371-376 (2020)

91. Saha, J., Begum, A., Mukherjee, A., Kumar, S.: A novel green synthesis of silver nanoparticles and their catalytic action in reduction of methylene blue dye. Sustain. Environ. Res. 27, 245-250 (2017)

92. Parveen, M., Ahmad, F., Malla, A.M., Azaz, S.: Microwaveassisted green synthesis of silver nanoparticles from Fraxinus excelsior leaf extract and its antioxidant assay. Appl. Nanosci. 6, 267-276 (2016)

93. Kaur, G., Kalia, A., Sodhi, H.S.: Size controlled, time-efficient biosynthesis of silver nanoparticles from Pleurotus florida using ultra-violet, visible range, and microwave radiations. Inorg. Nano-Met. Chem. 50, 35-41 (2020)

94. Zhang, S., Tang, Y., Vlahovic, B.: A review on preparation and applications of silver-containing nanofibers. Nanoscale Res. Lett. 11, 80 (2016)

95. Yeo, J., Kim, G., Hong, S., Kim, M.S., Kim, D., Lee, J., Lee, H.B., Kwon, J., Suh, Y.D., Kang, H.W.: Flexible supercapacitor fabrication by room temperature rapid laser processing of rollto-roll printed metal nanoparticle ink for wearable electronics application. J. Power Sources 246, 562-568 (2014)

96. Shi, Q., Vitchuli, N., Nowak, J., Noar, J., Caldwell, J.M., Breidt, F., Bourham, M., McCord, M., Zhang, X.: One-step synthesis of silver nanoparticle-filled nylon 6 nanofibers and their antibacterial properties. J. Mater. Chem. 21, 10330-10335 (2011)

97. Hsu, K.-C., Chen, D.-H.: Microwave-assisted green synthesis of $\mathrm{Ag} /$ reduced graphene oxide nanocomposite as a surfaceenhanced Raman scattering substrate with high uniformity. Nanoscale Res. Lett. 9, 1-9 (2014)

98. Li, J., Kuang, D., Feng, Y., Zhang, F., Xu, Z., Liu, M., Wang, D.: Green synthesis of silver nanoparticles-graphene oxide nanocomposite and its application in electrochemical sensing oftryptophan. Biosens. Bioelectron. 42, 198-206 (2013)

99. Vi, T.T.T., Rajesh Kumar, S., Rout, B., Liu, C.-H., Wong, C.-B., Chang, C.-W., Chen, C.-H., Chen, D.W., Lue, S.J.: The preparation of graphene oxide-silver nanocomposites: the effect of silver loads on Gram-positive and Gram-negative antibacterial activities. Nanomaterials 8, 163 (2018)

100. Xu, Y., Li, S., Yue, X., Lu, W.: Review of silver nanoparticles (AgNPs)-cellulose antibacterial composites. BioResources 13, 2150-2170 (2018)

101. Latif, U., Al-Rubeaan, K., Saeb, A.T.: A review on antimicrobial chitosan-silver nanocomposites: a roadmap toward pathogen targeted synthesis. Int. J. Polym. Mater. Polym. Biomater. 64, 448-458 (2015)

102. Fouda, M.M., El-Aassar, M., Al-Deyab, S.S.: Antimicrobial activity of carboxymethyl chitosan/polyethylene oxide nanofibers embedded silver nanoparticles. Carbohydr. Polym. 92, 10121017 (2013) 
103. Saravanan, S., Nethala, S., Pattnaik, S., Tripathi, A., Moorthi, A., Selvamurugan, N.: Preparation, characterization and antimicrobial activity of a bio-composite scaffold containing chitosan/ nano-hydroxyapatite/nano-silver for bone tissue engineering. Int. J. Biol. Macromol. 49, 188-193 (2011)

104. Wang, B.-L., Liu, X.-S., Ji, Y., Ren, K.-F., Ji, J.: Fast and longacting antibacterial properties of chitosan- $\mathrm{Ag} /$ polyvinylpyrrolidone nanocomposite films. Carbohydr. Polym. 90, 8-15 (2012)

105. Sadasivuni, K.K., Rattan, S., Waseem, S., Brahme, S.K., Kondawar, S.B., Ghosh, S., Das, A., Chakraborty, P.K., Adhikari, J., Saha, P.: Polymer Nanocomposites in Biomedical Engineering, pp. 331-373. Springer, New York (2019)

106. Zahed, B., Hosseini-Monfared, H.: A comparative study of silvergraphene oxide nanocomposites as a recyclable catalyst for the aerobic oxidation of benzyl alcohol: Support effect. Appl. Surf. Sci. 328, 536-547 (2015)

107. Ahmad, M.B., Lim, J.J., Shameli, K., Ibrahim, N.A., Tay, M.Y., Chieng, B.W.: Antibacterial activity of silver bionanocomposites synthesized by chemical reduction route. Chem. Cent. J. 6, 101 (2012)

108. Sámano-Valencia, C., Martínez-Castañón, G.A., MartínezMartínez, R.E., Loyola-Rodríguez, J.P., Reyes-Macías, J.F., Ortega-Zarzosa, G., Niño-Martínez, N.: Bactericide efficiency of a combination of chitosan gel with silver nanoparticles. Mater. Lett. 106, 413-416 (2013)

109. Ghosh, S., Ranebennur, T.K., Vasan, H.N.: Study of antibacterial efficacy of hybrid chitosan-silver nanoparticles for prevention of specific biofilm and water purification. Int. J. Carbohydr. Chem. 2011, 693759 (2011)

110. Tripathi, S., Mehrotra, G.K., Dutta, P.K.: Chitosan-silver oxide nanocomposite film: preparation and antimicrobial activity. Bull. Mater. Sci. 34, 29-35 (2011)

111. Calderón-Ayala, G., Cortez-Valadez, M., Martínez-Núñez, C., Flores-Acosta, M.: FLG/silver nanoparticles: nanocomposite by green synthesis. Diamond Relat. Mater. 101, 107618 (2020)

112. Zhang, Y., Liu, S., Wang, L., Qin, X., Tian, J., Lu, W., Chang, G., Sun, X.: One-pot green synthesis of Ag nanoparticles-graphene nanocomposites and their applications in SERS, $\mathrm{H}_{2} \mathrm{O}_{2}$, and glucose sensing. RSC Adv. 2, 538-545 (2012)

113. Yuan, W., Gu, Y., Li, L.: Green synthesis of graphene/Ag nanocomposites. Appl. Surf. Sci. 261, 753-758 (2012)

114. Raja, S., Ramesh, V., Thivaharan, V.: Green biosynthesis of silver nanoparticles using Calliandra haematocephala leaf extract, their antibacterial activity and hydrogen peroxide sensing capability. Arabian J. Chem. 10, 253-261 (2017)

115. Liu, H., Zhong, L., Yun, K., Samal, M.: Synthesis, characterization, and antibacterial properties of silver nanoparticles-graphene and graphene oxide composites. Biotechnol. Bioprocess Eng. 21, 1-18 (2016)

116. Sharma, S., Sanpui, P., Chattopadhyay, A., Ghosh, S.S.: Fabrication of antibacterial silver nanoparticle-sodium alginate-chitosan composite films. RSC Adv. 2, 5837-5843 (2012)

117. Lee, H., Hong, S., Kwon, J., Suh, Y.D., Lee, J., Moon, H., Yeo, J., Ko, S.H.: All-solid-state flexible supercapacitors by fast laser annealing of printed metal nanoparticle layers. J. Mater. Chem. A 3, 8339-8345 (2015)

118. Patil, D.S., Pawar, S.A., Patil, P.S., Kim, J.H., Shin, J.C.: Silver nanoparticles incorporated PEDOT-PSS electrodes for electrochemical supercapacitor. J. Nanosci. Nanotechnol. 16, 1062510629 (2016)

119. Das, C., Chatterjee, S., Kumaraswamy, G., Krishnamoorthy, K.: Elastic compressible energy storage devices from ICE templated polymer gels treated with polyphenols. J. Phys. Chem. C 121, 3270-3278 (2017)
120. Dhibar, S., Das, C.K.: Silver nanoparticles decorated polypyrrole/ graphene nanocomposite: a potential candidate for next-generation supercapacitor electrode material. J. Appl. Polym. Sci. 134 (2017)

121. Guo, Q., Ghadiri, R., Weigel, T., Aumann, A., Gurevich, E.L., Esen, C., Medenbach, O., Cheng, W., Chichkov, B., Ostendorf, A.: Comparison of in situ and ex situ methods for synthesis of two-photon polymerization polymer nanocomposites. Polymers 6, 2037-2050 (2014)

122. Li, Z., Yuan, X., Fu, L., Peng, K., Wang, F., Fu, X., Caroff, P., White, T.P., Tan, H.H., Jagadish, C.: Room temperature GaAsSb single nanowire infrared photodetectors. Nanotechnology 26 , 445202 (2015)

123. Bai, J., Li, Y., Du, J., Wang, S., Zheng, J., Yang, Q., Chen, X.: One-pot synthesis of polyacrylamide-gold nanocomposite. Mater. Chem. Phys. 106, 412-415 (2007)

124. Kumar, S.V., Huang, N., Lim, H., Zainy, M., Harrison, I., Chia, C.H.: Preparation of highly water dispersible functional graphene/silver nanocomposite for the detection of melamine. Sens. Actuators B 181, 885-893 (2013)

125. Liu, G., Wang, Y., Pu, X., Jiang, Y., Cheng, L., Jiao, Z.: Onestep synthesis of high conductivity silver nanoparticle-reduced graphene oxide composite films by electron beam irradiation. Appl. Surf. Sci. 349, 570-575 (2015)

126. Sadrolhesseini, A.R., Noor, A., Mahdi, M., Kharazmi, A., Zakaria, A., Yunus, W., Huang, N.: 2013 IEEE 4th International Conference on Photonics (ICP). IEEE, pp. 62-65 (2013)

127. Lan, N.T., Dinh, N.X., Hung, N.D., Lan, H., Tuan, P.A., Trung, N.N., Hoa, N.Q., Huy, T.Q., Van Quy, N., Duong, T.-T.: Photochemical decoration of silver nanoparticles on graphene oxide nanosheets and their optical characterization. J. Alloys Compd. 615, 843-848 (2014)

128. Veerapandian, M., Kim, H.Y., Seo, Y.-T., Lee, K.-N., Yun, K., Lee, M.-H.: Metalloid polymer nanoparticle functionalized graphene oxide working electrode for durable glucose sensing. Mater. Res. Bull. 49, 593-600 (2014)

129. Veerapandian, M., Neethirajan, S.: Graphene oxide chemically decorated with $\mathrm{Ag}-\mathrm{Ru} /$ chitosan nanoparticles: fabrication, electrode processing and immunosensing properties. RSC Adv. 5, 75015-75024 (2015)

130. Zheng, J.-N., Li, S.-S., Ma, X., Chen, F.-Y., Wang, A.-J., Chen, J.-R., Feng, J.-J.: Green synthesis of core-shell gold-palladium@ palladium nanocrystals dispersed on graphene with enhanced catalytic activity toward oxygen reduction and methanol oxidation in alkaline media. J. Power Sources 262, 270-278 (2014)

131. Kim, K.K., Reina, A., Shi, Y., Park, H., Li, L.-J., Lee, Y.H., Kong, J.: Enhancing the conductivity of transparent graphene films via doping. Nanotechnology 21, 285205 (2010)

132. Benavente, J., Garcia, M., Urbano, N., Lopez-Romero, J., Contreras-Caceres, R., Casado-Rodriguez, M., Moscoso, A., Hierrezuelo, J.: Inclusion of silver nanoparticles for improving regenerated cellulose membrane performance and reduction of biofouling. Int. J. Biol. Macromol. 103, 758-763 (2017)

133. Kendouli, S., Sobti, N., Bensouissi, A., Avci, A., Eskizeybek, V., Achour, S.: Modification of cellulose acetate nanofibers with PVP/Ag addition. Mater. Sci. Semicond. Process. 28, 13-19 (2014)

134. Martins, N.C., Freire, C.S., Pinto, R.J., Fernandes, S.C., Neto, C.P., Silvestre, A.J., Causio, J., Baldi, G., Sadocco, P., Trindade, T.: Electrostatic assembly of Ag nanoparticles onto nanofibrillated cellulose for antibacterial paper products. Cellulose 19, 1425-1436 (2012)

135. Brobbey, K.J., Haapanen, J., Gunell, M., Mäkelä, J.M., Eerola, E., Toivakka, M., Saarinen, J.J.: One-step flame synthesis of 
silver nanoparticles for roll-to-roll production of antibacterial paper. Appl. Surf. Sci. 420, 558-565 (2017)

136. Elayaraja, S., Zagorsek, K., Li, F., Xiang, J.: In situ synthesis of silver nanoparticles into TEMPO-mediated oxidized bacterial cellulose and their antivibriocidal activity against shrimp pathogens. Carbohydr. Polym. 166, 329-337 (2017)

137. Gaminian, H., Montazer, M.: Decorating silver nanoparticles on electrospun cellulose nanofibers through a facile method by dopamine and ultraviolet irradiation. Cellulose 24, 3179-3190 (2017)

138. Muthulakshmi, L., Rajini, N., Rajalu, A.V., Siengchin, S., Kathiresan, T.: Synthesis and characterization of cellulose/ silver nanocomposites from bioflocculant reducing agent. Int. J. Biol. Macromol. 103, 1113-1120 (2017)

139. Ramaraju, B., Imae, T., Destaye, A.G.: Ag nanoparticle-immobilized cellulose nanofibril films for environmental conservation. Appl. Catal. A 492, 184-189 (2015)

140. Yoksan, R., Chirachanchai, S.: Silver nanoparticles dispersing in chitosan solution: Preparation by $\gamma$-ray irradiation and their antimicrobial activities. Mater. Chem. Phys. 115, 296-302 (2009)

141. Shameli, K., Ahmad, M.B., Yunus, W.M.Z.W., Rustaiyan, A., Ibrahim, N.A., Zargar, M., Abdollahi, Y.: Green synthesis of silver/montmorillonite/chitosan bionanocomposites using the UV irradiation method and evaluation of antibacterial activity. Int. J. Nanomed. 5, 875 (2010)

142. Rao, K.K., Reddy, P.R., Lee, Y.-I., Kim, C.: Synthesis and characterization of chitosan-PEG-Ag nanocomposites for antimicrobial application. Carbohydr. Polym. 87, 920-925 (2012)

143. Shameli, K., Ahmad, M.B., Zargar, M., Yunus, W.M.Z.W., Ibrahim, N.A., Shabanzadeh, P., Moghaddam, M.G.: Synthesis and characterization of silver/montmorillonite/chitosan bionanocomposites by chemical reduction method and their antibacterial activity. Int. J. Nanomed. 6, 271 (2011)

144. Thomas, V., Bajpai, M., Bajpai, S.: In situ formation of silver nanoparticles within chitosan-attached cotton fabric for antibacterial property. J. Ind. Text. 40, 229-245 (2011)

145. Pinto, R.J., Fernandes, S.C., Freire, C.S., Sadocco, P., Causio, J., Neto, C.P., Trindade, T.: Antibacterial activity of optically transparent nanocomposite films based on chitosan or its derivatives and silver nanoparticles. Carbohydr. Res. 348, 77-83 (2012)

146. Ghosh, S., Ranebennur, T.K., Vasan, H.: Study of antibacterial efficacy of hybrid chitosan-silver nanoparticles for prevention of specific biofilm and water purification. Int. J. Carbohydr. Chem. 2011, 693879 (2011)

147. Vimala, K., Mohan, Y.M., Sivudu, K.S., Varaprasad, K., Ravindra, S., Reddy, N.N., Padma, Y., Sreedhar, B., MohanaRaju, K.: Fabrication of porous chitosan films impregnated with silver nanoparticles: a facile approach for superior antibacterial application. Colloids Surf. B 76, 248-258 (2010)

148. Reicha, F.M., Sarhan, A., Abdel-Hamid, M.I., El-Sherbiny, I.M.: Preparation of silver nanoparticles in the presence of chitosan by electrochemical method. Carbohydr. Polym. 89, 236-244 (2012)

149. Naikoo, G.A., Mustaqeem, M., Hassan, I.U., Awan, T., Arshad, F., Salim, H., Qurashi, A.: Bioinspired and green synthesis of nanoparticles from plant extracts with antiviral and antimicrobial properties: a critical review. J. Saudi Chem. Soc. 25, 101304 (2021)

150. Bapat, R.A., Chaubal, T.V., Joshi, C.P., Bapat, P.R., Choudhury, H., Pandey, M., Gorain, B., Kesharwani, P.: An overview of application of silver nanoparticles for biomaterials in dentistry. Mater. Sci. Eng. C 91, 881-898 (2018)

151. Khorrami, S., Zarrabi, A., Khaleghi, M., Danaei, M., Mozafari, M.R.: Selective cytotoxicity of green synthesized silver nanoparticles against the MCF-7 tumor cell line and their enhanced antioxidant and antimicrobial properties. Int. J. Nanomed. 13, 8013 (2018)

152. Ramkumar, V.S., Pugazhendhi, A., Gopalakrishnan, K., Sivagurunathan, P., Saratale, G.D., Dung, T.N.B., Kannapiran, E.: Biofabrication and characterization of silver nanoparticles using aqueous extract of seaweed Enteromorpha compressa and its biomedical properties. Biotech. Rep. 14, 1-7 (2017)

153. Govindappa, M., Tejashree, S., Thanuja, V., Hemashekhar, B., Srinivas, C., Nasif, O., Pugazhendhi, A., Raghavendra, V.B.: Pomegranate fruit fleshy pericarp mediated silver nanoparticles possessing antimicrobial, antibiofilm formation, antioxidant, biocompatibility and anticancer activity. J. Drug Delivery Sci. Technol. 61, 102289 (2021)

154. Stabryla, L.M., Johnston, K.A., Diemler, N.A., Cooper, V.S., Millstone, J.E., Haig, S.-J., Gilbertson, L.M.: Role of bacterial motility in differential resistance mechanisms of silver nanoparticles and silver ions. Nat. Nanotechol. 16, 996-1003 (2021)

155. Crisan, C.M., Mocan, T., Manolea, M., Lasca, L.I., Tăbăran, F.-A., Mocan, L.: Review on silver nanoparticles as a novel class of antibacterial solutions. Appl. Sci. 11, 1120 (2021)

156. Kailasa, S.K., Park, T.-J., Rohit, J.V., Koduru, J.R.: Nanoparticles in Pharmacotherapy, pp. 461-484. Elsevier, Amsterdam (2019)

157. Nakamura, S., Sato, M., Sato, Y., Ando, N., Takayama, T., Fujita, M., Ishihara, M.: Synthesis and application of silver nanoparticles (Ag NPs) for the prevention of infection in healthcare workers. Int. J. Mol. Sci. 20, 3620 (2019)

158. Sinclair, T.R., van den Hengel, S.K., Raza, B.G., Rutjes, S.A., de Roda Husman, A.M., Peijnenburg, W.J.G.M., Roesink, H.E.D.W., de Vos, W.M.: Surface chemistry-dependent antiviral activity of silver nanoparticles. Nanotechnology 32, 365101 (2021)

159. Ismail, G.A., El-Sheekh, M.M., Samy, R.M., Gheda, S.F.: Antimicrobial, antioxidant, and antiviral activities of biosynthesized silver nanoparticles by phycobiliprotein crude extract of the cyanobacteria Spirulina platensis and Nostoc linckia. Bionanoscience 11, 355-370 (2021)

160. Calderón-Jiménez, B., Johnson, M.E., Montoro Bustos, A.R., Murphy, K.E., Winchester, M.R., Vega Baudrit, J.R.: Silver nanoparticles: technological advances, societal impacts, and metrological challenges. Front. Chem. 5, 6 (2017)

161. Mackevica, A., Olsson, M.E., Hansen, S.F.: The release of silver nanoparticles from commercial toothbrushes. J. Hazard. Mater. 322, 270-275 (2017)

162. Mallakpour, S., Hussain, C.M., Abdukhakimov, M., Khaydarov, R., Krishnamurthy, P.T., Evgrafova, S.: Silver-nanoparticle-embedded antimicrobial paints. In: Handbook of Consumer Nanoproducts, pp. 1-10 (2021)

163. Baram-Pinto, D., Shukla, S., Perkas, N., Gedanken, A., Sarid, R.: Inhibition of herpes simplex virus type 1 infection by silver nanoparticles capped with mercaptoethane sulfonate. Bioconjugate Chem. 20, 1497-1502 (2009)

164. Du, T., Liang, J., Dong, N., Lu, J., Fu, Y., Fang, L., Xiao, S., Han, H.: Glutathione-capped Ag2S nanoclusters inhibit coronavirus proliferation through blockage of viral RNA synthesis and budding. ACS Appl. Mater. Interfaces 10, 4369-4378 (2018)

165. Castro-Mayorga, J.L., Randazzo, W., Fabra, M.J., Lagaron, J.M., Aznar, R., Sánchez, G.: Antiviral properties of silver nanoparticles against norovirus surrogates and their efficacy in coated polyhydroxyalkanoates systems. LWT Food Sci. Technol. 79, 503-510 (2017)

166. Rogers, J.V., Parkinson, C.V., Choi, Y.W., Speshock, J.L., Hussain, S.M.: A preliminary assessment of silver nanoparticle inhibition of monkeypox virus plaque formation. Nanoscale Res. Lett. 3, 129 (2008) 
167. Speshock, J.L., Murdock, R.C., Braydich-Stolle, L.K., Schrand, A.M., Hussain, S.M.: Interaction of silver nanoparticles with Tacaribe virus. J. Nanobiotechnol. 8, 1-9 (2010)

168. Lara, H.H., Ayala-Nuñez, N.V., Ixtepan-Turrent, L., RodriguezPadilla, C.: Mode of antiviral action of silver nanoparticles against HIV-1. J. Nanobiotechnol. 8, 1 (2010)

169. Sharma, R.K., Cwiklinski, K., Aalinkeel, R., Reynolds, J.L., Sykes, D.E., Quaye, E., Oh, J., Mahajan, S.D., Schwartz, S.A.: Immunomodulatory activities of curcumin-stabilized silver nanoparticles: efficacy as an antiretroviral therapeutic. Immunol. Invest. 46, 833-846 (2017)

170. Lu, L., Sun, R., Chen, R., Hui, C.-K., Ho, C.-M., Luk, J., Lau, G., Che, C.-M.: Silver nanoparticles inhibit hepatitis B virus replication. Antiviral Ther. 13, 253-262 (2008)

171. Sun, L., Singh, A.K., Vig, K., Pillai, S.R., Singh, S.R.: Silver nanoparticles inhibit replication of respiratory syncytial virus. J. Biomed. Nanotechnol. 4, 149-158 (2008)

172. Morris, D., Ansar, M., Speshock, J., Ivanciuc, T., Qu, Y., Casola, A., Garofalo, R.P.: Antiviral and immunomodulatory activity of silver nanoparticles in experimental RSV infection. Viruses 11, 732 (2019)

173. Sofy, A.R., Hmed, A.A., Abd El Haliem, N.F., Zein, M.A.E., Elshaarawy, R.F.M.: Polyphosphonium-oligochitosans decorated with nanosilver as new prospective inhibitors for common human enteric viruses. Carbohydr. Polym. 226, 115261 (2019)

174. Mori, Y., Ono, T., Miyahira, Y., Nguyen, V.Q., Matsui, T., Ishihara, M.: Antiviral activity of silver nanoparticle/chitosan composites against H1N1 influenza A virus. Nanoscale Res. Lett. 8, 93 (2013)

175. Li, Y., Lin, Z., Zhao, M., Xu, T., Wang, C., Hua, L., Wang, H., Xia, H., Zhu, B.: Silver nanoparticle based codelivery of oseltamivir to inhibit the activity of the H1N1 influenza virus through ROS-mediated signaling pathways. ACS Appl. Mater. Interfaces 8, 24385-24393 (2016)

176. Xiang, D., Zheng, Y., Duan, W., Li, X., Yin, J., Shigdar, S., O'Connor, M.L., Marappan, M., Zhao, X., Miao, Y.: Inhibition of A/Human/Hubei/3/2005 (H3N2) influenza virus infection by silver nanoparticles in vitro and in vivo. Int. J. Nanomed. 8, 4103 (2013)

177. Park, S., Ko, Y.-S., Lee, S.J., Lee, C., Woo, K., Ko, G.: Inactivation of influenza A virus via exposure to silver nanoparticledecorated silica hybrid composites. Environ. Sci. Pollut. Res. 25, 27021-27030 (2018)

178. Villeret, B., Dieu, A., Straube, M., Solhonne, B., Miklavc, P., Hamadi, S., Le Borgne, R.M., Mailleux, A., Norel, X., Aerts, J.: Silver nanoparticles impair retinoic acid-inducible gene I-mediated mitochondrial antiviral immunity by blocking the autophagic flux in lung epithelial cells. ACS Nano 12,11881202 (2018)

179. Park, S., Park, H.H., Kim, S.Y., Kim, S.J., Woo, K., Ko, G.: Antiviral properties of silver nanoparticles on a magnetic hybrid colloid. Appl. Environ. Microbiol. 80, 2343-2350 (2014)

180. Tran, D.N., Vu, N.N., Nhan, T., Bich, N.T.T., Quang, M.L., To, N.B., Le Van, P., Dang, V.Q.: Silver nanoparticles as potential antiviral agents against African swine fever virus. Mater. Res. Express 17, 1-7 (2020)

181. Romo-Quiñonez, C.R., Álvarez-Sánchez, A.R., Álvarez-Ruiz, P., Chávez-Sánchez, M.C., Bogdanchikova, N., Pestryakov, A., Mejia-Ruiz, C.H.: Evaluation of a new Argovit as an antiviral agent included in feed to protect the shrimp Litopenaeus vannamei against White Spot Syndrome Virus infection. PeerJ 8, e8446 (2020)

182. Mori, Y., Tagawa, T., Fujita, M., Kuno, T., Suzuki, S., Matsui, T., Ishihara, M.: Simple and environmentally friendly preparation and size control of silver nanoparticles using an inhomogeneous system with silver-containing glass powder. J. Nanopart. Res. 13, 2799-2806 (2011)

183. Gaikwad, S., Ingle, A., Gade, A., Rai, M., Falanga, A., Incoronato, N., Russo, L., Galdiero, S., Galdiero, M.: Antiviral activity of mycosynthesized silver nanoparticles against herpes simplex virus and human parainfluenza virus type 3 . Int. J. Nanomed. 8, 4303 (2013)

184. De Gusseme, B., Sintubin, L., Baert, L., Thibo, E., Hennebel, T., Vermeulen, G., Uyttendaele, M., Verstraete, W., Boon, N.: Biogenic silver for disinfection of water contaminated with viruses. Appl. Environ. Microbiol. 76, 1082-1087 (2010)

185. Sreekanth, T.V.M., Nagajyothi, P.C., Muthuraman, P., Enkhtaivan, G., Vattikuti, S.V.P., Tettey, C.O., Kim, D.H., Shim, J., Yoo, K.: Ultra-sonication-assisted silver nanoparticles using Panax ginseng root extract and their anti-cancer and antiviral activities. J. Photochem. Photobiol. B 188, 6-11 (2018)

186. Ramadan, M.A., Shawkey, A.E., Rabeh, M.A., Abdellatif, A.O.: Promising antimicrobial activities of oil and silver nanoparticles obtained from Melaleuca alternifolia leaves against selected skin-infecting pathogens. J. Herb. Med. 20, 100289 (2020)

187. Dhanasezhian, A., Srivani, S., Govindaraju, K., Parija, P., Sasikala, S., Kumar, M.R.: Anti-herpes simplex virus (HSV-1 and HSV-2) activity of biogenic gold and silver nanoparticles using seaweed Sargassum wightii. Ind. J. Geo Mar. Sci. 48, 1252-1257 (2019)

188. Orłowski, P., Kowalczyk, A., Tomaszewska, E., Ranoszek-Soliwoda, K., Węgrzyn, A., Grzesiak, J., Celichowski, G., Grobelny, J., Eriksson, K., Krzyzowska, M.: Antiviral activity of tannic acid modified silver nanoparticles: potential to activate immune response in herpes genitalis. Viruses 10, 524 (2018)

189. Choudhary, S., Kumar, R., Dalal, U., Tomar, S., Reddy, S.N.: Green synthesis of nanometal impregnated biomass-antiviral potential. Mater. Sci. Eng. C 112, 110934 (2020)

190. Wan, C., Tai, J., Zhang, J., Guo, Y., Zhu, Q., Ling, D., Gu, F., Gan, J., Zhu, C., Wang, Y.: Silver nanoparticles selectively induce human oncogenic $\gamma$-herpesvirus-related cancer cell death through reactivating viral lytic replication. Cell Death Dis. 10, 1-16 (2019)

191. Khandelwal, N., Kaur, G., Chaubey, K.K., Singh, P., Sharma, S., Tiwari, A., Singh, S.V., Kumar, N.: Silver nanoparticles impair Peste des petits ruminants virus replication. Virus Res. 190, 1-7 (2014)

192. Elbeshehy, E.K.F., Elazzazy, A.M., Aggelis, G.: Silver nanoparticles synthesis mediated by new isolates of Bacillus spp., nanoparticle characterization and their activity against Bean Yellow Mosaic Virus and human pathogens. Front. Microbiol. 6, 453 (2015)

193. Khalid, M., Khalid, N., Ahmed, I., Hanif, R., Ismail, M., Janjua, H.A.: Comparative studies of three novel freshwater microalgae strains for synthesis of silver nanoparticles: insights of characterization, antibacterial, cytotoxicity and antiviral activities. J. Appl. Phycol. 29, 1851-1863 (2017)

194. Speshock, J.L., Murdock, R.C., Braydich-Stolle, L.K., Schrand, A.M., Hussain, S.M.: Interaction of silver nanoparticles with Tacaribe virus. J. Nanobiotechnol. 8, 19 (2010)

195. Sanchez-Guzman, D., Le Guen, P., Villeret, B., Sola, N., Le Borgne, R., Guyard, A., Kemmel, A., Crestani, B., Sallenave, J.-M., Garcia-Verdugo, I.: Silver nanoparticle-adjuvanted vaccine protects against lethal influenza infection through inducing BALT and IgA-mediated mucosal immunity. Biomaterials 217, 119308 (2019)

196. Villeret, B., Dieu, A., Straube, M., Solhonne, B., Miklavc, P., Hamadi, S., Le Borgne, R., Mailleux, A., Norel, X., Aerts, J., Diallo, D., Rouzet, F., Dietl, P., Sallenave, J.-M., Garcia-Verdugo, I.: Silver nanoparticles impair retinoic acid-inducible gene I-mediated mitochondrial antiviral immunity by blocking the 
autophagic flux in lung epithelial cells. ACS Nano 12, 1188$1202(2018)$

197. Borrego, B., Lorenzo, G., Mota-Morales, J.D., Almanza-Reyes, H., Mateos, F., López-Gil, E., de la Losa, N., Burmistrov, V.A., Pestryakov, A.N., Brun, A., Bogdanchikova, N.: Potential application of silver nanoparticles to control the infectivity of Rift Valley fever virus in vitro and in vivo. Nanomedicine 12, 11851192 (2016)

198. Lv, X., Wang, P., Bai, R., Cong, Y., Suo, S., Ren, X., Chen, C.: Inhibitory effect of silver nanomaterials on transmissible virusinduced host cell infections. Biomaterials 35, 4195-4203 (2014)

199. Elazzazy, A.M., Elbeshehy, E.K., Betiha, M.A.: In vitro assessment of activity of graphene silver composite sheets against multidrug-resistant bacteria and Tomato Bushy Stunt Virus. Trop. J. Pharm. Res. 16, 2705-2711 (2017)

200. Ramadan, M.A., Shawkey, A.E., Rabeh, M.A., Abdellatif, A.O.: Promising antimicrobial activities of oil and silver nanoparticles obtained from Melaleuca alternifolia leaves against selected skin-infecting pathogens. J. Herb. Med. 20, 100289 (2019)

201. Jamkhande, P.G., Ghule, N.W., Bamer, A.H., Kalaskar, M.G.: Metal nanoparticles synthesis: an overview on methods of preparation, advantages and disadvantages, and applications. J. Drug Delivery Sci. Technol. 53, 101174 (2019)

202. Prabhu, S., Poulose, E.K.: Silver nanoparticles: mechanism of antimicrobial action, synthesis, medical applications, and toxicity effects. Int. Nano Lett. 2, 32 (2012)

203. Shenashen, M.A., El-Safty, S.A., Elshehy, E.A.: Synthesis, morphological control, and properties of silver nanoparticles in potential applications. Part. Part. Syst. Charact. 31, 293-316 (2014)

204. Baklacı, D., Kum, R.O., Kulaçoğlu, S., Yılmaz, Y.F., Özcan, M.: The effects of MESNA on the facial nerve, an experimental animal study. J. Int. Adv. Otol. 14, 63-67 (2018)

205. Velte, J.S.: Acute toxicity of hydrazine hydrate to the fathead minnow (Pimephales promelas) and daphnid (Daphnia pulex). Bull. Environ. Contam. Toxicol. 33, 598-604 (1984)

206. Peng, S.W., Guo, X.Y., Shang, G.G., Li, J., Xu, X.Y., You, M.L., Li, P., Chen, G.Q.: An assessment of the risks of carcinogenicity associated with polyhydroxyalkanoates through an analysis of DNA aneuploid and telomerase activity. Biomaterials 32, 2546-2555 (2011)

207. Gudikandula, K., Charya Maringanti, S.: Synthesis of silver nanoparticles by chemical and biological methods and their antimicrobial properties. J. Exp. Nanosci. 11, 714-721 (2016)

208. Galdiero, S., Falanga, A., Cantisani, M., Ingle, A., Galdiero, M., Rai, M.: Handbook of Nanobiomedical Research: Fundamentals, Applications and Recent Developments: Volume 1. Materials for Nanomedicine. World Scientific, pp. 565-594 (2014)

209. Venkatesan, B., Subramanian, V., Tumala, A., Vellaichamy, E.: Rapid synthesis of biocompatible silver nanoparticles using aqueous extract of Rosa damascena petals and evaluation of their anticancer activity. Asian Pac. J. Trop. Med. 7, S294-S300 (2014)

210. Jia, H., Titmuss, S.: Polymer-functionalized nanoparticles: from stealth viruses to biocompatible quantum dots. Nanomedicine $\mathbf{4}$, 951-966 (2009)

211. Lee, J.S., Ko, E.-J., Hwang, H.S., Lee, Y.-N., Kwon, Y.-M., Kim, M.-C., Kang, S.-M.: Antiviral activity of ginseng extract against respiratory syncytial virus infection. Int. J. Mol. Med. 34, 183-190 (2014)

212. Kachur, K., Suntres, Z.E.: The antimicrobial properties of ginseng and ginseng extracts. Expert Rev. Anti-Infect. Ther. 14, 81-94 (2016)

213. Roy, A., Bulut, O., Some, S., Mandal, A.K., Yilmaz, M.D.: Green synthesis of silver nanoparticles: biomolecule-nanoparticle organizations targeting antimicrobial activity. RSC Adv. 9, 2673-2702 (2019)

214. Pangestika, R., Ernawati, R.: Antiviral activity effect of silver nanoparticles (Agnps) solution against the growth of infectious bursal disease virus on embryonated chicken eggs with Elisa test. KnE Life Sci. 536-548 (2017)

215. Zhang, X.-F., Liu, Z.-G., Shen, W., Gurunathan, S.: Silver nanoparticles: synthesis, characterization, properties, applications, and therapeutic approaches. Int. J. Mol. Sci. 17, 1534 (2016)

216. Huy, T.Q., Thanh, N.T.H., Thuy, N.T., Van Chung, P., Hung, P.N., Le, A.-T., Hanh, N.T.H.: Cytotoxicity and antiviral activity of electrochemical-synthesized silver nanoparticles against poliovirus. J. Virol. Methods 241, 52-57 (2017)

217. Akbarzadeh, A., Kafshdooz, L., Razban, Z., Dastranj Tbrizi, A., Rasoulpour, S., Khalilov, R., Kavetskyy, T., Saghfi, S., Nasibova, A.N., Kaamyabi, S.: An overview application of silver nanoparticles in inhibition of herpes simplex virus. Artif. Cells Nanomed. Biotechnol. 46, 263-267 (2018)

218. Shady, N.H., Khattab, A.R., Ahmed, S., Liu, M., Quinn, R.J., Fouad, M.A., Kamel, M.S., Muhsinah, A.B., Krischke, M., Mueller, M.J.: Hepatitis C virus NS3 protease and helicase inhibitors from Red Sea sponge (Amphimedon) species in green synthesized silver nanoparticles assisted by in silico modeling and metabolic profiling. Int. J. Nanomed. 15, 3377 (2020)

219. Kummara, S., Patil, M.B., Uriah, T.: Synthesis, characterization, biocompatible and anticancer activity of green and chemically synthesized silver nanoparticles-a comparative study. Biomed. Pharmacother. 84, 10-21 (2016)

220. Akter, M., Sikder, M.T., Rahman, M.M., Ullah, A.K.M.A., Hossain, K.F.B., Banik, S., Hosokawa, T., Saito, T., Kurasaki, M.: A systematic review on silver nanoparticles-induced cytotoxicity: physicochemical properties and perspectives. J. Adv. Res. 9, $1-16(2018)$

221. van der Zande, M., Vandebriel, R.J., Van Doren, E., Kramer, E., Herrera Rivera, Z., Serrano-Rojero, C.S., Gremmer, E.R., Mast, J., Peters, R.J.B., Hollman, P.C.H., Hendriksen, P.J.M., Marvin, H.J.P., Peijnenburg, A.A.C.M., Bouwmeester, H.: Distribution, elimination, and toxicity of silver nanoparticles and silver ions in rats after 28-day oral exposure. ACS Nano 6, 7427-7442 (2012)

222. Moradi-Sardareh, H., Basir, H.R.G., Hassan, Z.M., Davoudi, M., Amidi, F., Paknejad, M.: Toxicity of silver nanoparticles on different tissues of Balb/C mice. Life sci. 211, 81-90 (2018)

223. Faedmaleki, F., Shirazi, F.H., Salarian, A.-A., Ashtiani, H.A., Rastegar, H.: Toxicity effect of silver nanoparticles on mice liver primary cell culture and HepG2 cell line. Iran. J. Pharm. Res. 13, 235 (2014)

224. Gopinath, V., Priyadarshini, S., Loke, M.F., Arunkumar, J., Marsili, E., MubarakAli, D., Velusamy, P., Vadivelu, J.: Biogenic synthesis, characterization of antibacterial silver nanoparticles and its cell cytotoxicity. Arabian J. Chem. 10, 1107-1117 (2017)

225. Keshari, A., Srivastava, R., Yadav, S., Nath, G., Gond, S.: Synergistic activity of green silver nanoparticles with antibiotics. Nanomed. Res. J. 5, 44-54 (2020)

226. Koduru, J.R., Kailasa, S.K., Bhamore, J.R., Kim, K.-H., Dutta, T., Vellingiri, K.: Phytochemical-assisted synthetic approaches for silver nanoparticles antimicrobial applications: a review. Adv. Colloid Interface Sci. 256, 326-339 (2018)

227. David, L., Moldovan, B., Vulcu, A., Olenic, L., Perde-Schrepler, M., Fischer-Fodor, E., Florea, A., Crisan, M., Chiorean, I., Clichici, S.: Green synthesis, characterization and anti-inflammatory activity of silver nanoparticles using European black elderberry fruits extract. Colloids Surf. B 122, 767-777 (2014)

228. Etemadzade, M., Ghamarypour, A., Zabihollahi, R., Shirazi, M., Sahebjamee, H., Vaziri, A.Z., Assadi, A., Ardestani, M.S., Shandiz, S.A.S., Aghasadeghi, M.R.: Synthesis and evaluation of antiviral activities of novel sonochemical silver nanorods against 
HIV and HSV viruses. Asian Pac. J. Trop. Dis. 6, 854-858 (2016)

229. Siadati, S.A., Afzali, M., Sayyadi, M.: Could silver nano-particles control the 2019-nCoV virus? An urgent glance to the past. Chem. Sci. Rev. Lett. 3, 9-11 (2020)

230. Assis, M., Simoes, L.G.P., Tremiliosi, G.C., Ribeiro, L.K., Coelho, D., Minozzi, D.T., Santos, R.I., Vilela, D.C.B., Mascaro, L.H., Andrés, J.: PVC-SiO2-Ag composite as a powerful biocide and anti-SARS-CoV-2 material. J. Poly. Res. 28, 1-7 (2021)

231. Djellabi, R., Basilico, N., Delbue, S., D’Alessandro, S., Parapini, S., Cerrato, G., Laurenti, E., Falletta, E., Bianchi, C.L.: Oxidative inactivation of SARS-CoV-2 on photoactive AgNPs@ $\mathrm{TiO}_{2}$ ceramic tiles. Int. J. Mol. Sci. 22, 8836 (2021)

232. Shereen, M.A., Khan, S., Kazmi, A., Bashir, N., Siddique, R.: COVID-19 infection: Origin, transmission, and characteristics of human coronaviruses. J. Adv. Res. 24, 91-98 (2020)
233. Sarkar, S.: Silver nanoparticles with bronchodilators through nebulisation to treat COVID 19 patients. Curr. Med. Res. Opin. 3, 449-450 (2020)

234. Sportelli, M.C., Izzi, M., Kukushkina, E.A., Hossain, S.I., Picca, R.A., Ditaranto, N., Cioffi, N.: Can nanotechnology and materials science help the fight against SARS-CoV-2? Nanomaterials 10, $802(2020)$

235. Ball, P.: How nano can fight the virus. Nat. Mater. 20, 126-126 (2021)

Publisher's Note Springer Nature remains neutral with regard to jurisdictional claims in published maps and institutional affiliations.

\section{Authors and Affiliations}

\section{Jaison Jeevanandam ${ }^{1}$ - Saravanan Krishnan ${ }^{2} \cdot$ Yiik Siang Hii $^{3}$. Sharadwata Pan ${ }^{4} \cdot$ Yen San Chan $^{5} \cdot$ Caleb Acquah $^{6}$. Michael K. Danquah ${ }^{7}$. João Rodrigues ${ }^{1,7}$}

1 CQM-Centro de Química da Madeira, MMRG, Universidade da Madeira, Campus da Penteada, 9020-105 Funchal, Portugal

2 R \& D Division, Creative Carbon Labs Pvt Ltd, Chennai 600113, India

3 Singapore Centre for Environmental Life Sciences Engineering, Nanyang Technological University, 639798 Singapore, Singapore

4 TUM School of Life Sciences, Technical University of Munich, 85354 Freising, Germany
5 Department of Chemical and Energy Engineering, Faculty of Engineering and Science, Curtin University, CDT 250, 98009 Miri, Sarawak, Malaysia

6 Department of Chemical Engineering, University of Tennessee, Chattanooga, TN 37403, USA

7 School of Materials Science and Engineering, Center for Nano Energy Materials, Northwestern Polytechnical University, Xi' an 710072, China 